\title{
AN ENVIRONMENTAL ASSESSMENT OF PUBLIC PRIMARY SCHOOLS OF ISLAMABAD AND PROPOSED REMODELING FOR ONE SELECTED SCHOOL
}

\author{
Saima Iqbal* \\ Nomana Anjum** \\ Nazia Iftakhar***
}

\begin{abstract}
Current research interest in sustainable built environment is compelling architects, engineers and designers to re-visit the existing buildings to evaluate them on environmental criteria and to assess if the building is conducive to accommodate the user needs. Such type of research, focusing on school buildings, has demonstrated that environmental features including thermal comfort, lighting, indoor air quality, acoustic and provision of open spaces, impact the performance of students and teaching staff both physically and psychologically. The paper discusses the state of government school buildings in Islamabad. Post occupancy evaluation technique has been adopted to evaluate the school buildings. Extensive case studies are carried out on five school buildings drawn from the existing Federal Government (FG) Schools (one each from the five sectors) on account of said environmental features conducive to student learning. The research is carried out in two phases; first phase comprises data collection through questionnaire surveys and observation sheets from students and teachers about their perception and satisfaction for various environmental features. In second phase the environmental meters had been used to record the temperature, lighting and acoustic levels in the selected schools. Findings from research have been compared with international and national standards, and directed to identify the inadequacies and design draw backs. The study has revealed that space standards are much below the international standards and existing classes are very cramped in most cases. There are also design flaws in lighting, thermal comfort and acoustics and essential facilities are either missing or are substandard in most cases. Finally, an attempt is made to remodel one of the five schools studied and identified as lowest in meeting the environmental features. The research concludes with recommendations applicable for remodeling of existing schools or for the construction of new primary school buildings.
\end{abstract}

Keywords: User-friendly architectural design, Sustainable building design, Environmental quality of school buildings, Conducive environment, Post Occupancy Evaluation.

\section{INTRODUCTION}

Historically, buildings were assessed and analyzed more for their shape, form and structural designs and less for their performance in relation to user needs. Similarly, the concern for ecological principles such as use of sustainable building materials, conservation of water and energy, use of appropriate technology, air and water pollution control measures and waste reduction and management strategies were ignored or overlooked for long (Vezzoli, 2003). According to Scheuer et al. (2003), for the last two to three decades the need for sustainable development is argued as a need for harmony among the environment, society and economy. It focuses on improving the quality of life for all without increasing the use of natural resources (Langston \& Ding, 2001). Shah et al (2009) described ecological design principles which apply to all types of buildings and user friendly designs including all users of a specific building type. In the context of sustainable school environment the emphasis needs to be on design, planning and construction of any school considering that the physical facility influences the learning climate (PPRC, 2004) and also to minimize the environmental changes/ degradation in this process (Ohrenshall, 1999).

Bee (1985) argued that research studies on child development have established that young children's intellectual development is directly related with provision of stimulating learning environment in schools. Graca et al, 2007 described optimal learning environment as the one that includes thermal comfort, adequate ambience, noise control provision and physical facilities that directly help students to enjoy the learning process and help teachers to optimize the teaching

* Engineer Saima Iqbal, Lecturer Environmental Design at Allama Iqbal Open University, Islamabad.

** Dr. Nomana Anjum, Associate Professor /Chairperson, Environmental Design Programme at Allama Iqbal Open University, Islamabad.

*** Architect Nazia Iftakhar, Visiting Faculty Environmental Design Programme at Allama Iqbal Open University, Islamabad. 
experience. Children spend 40-45 hours per week in school environment, therefore apart from academic learning they are also expected to nurture their social, emotional and physical skills in the school environment. Pushkar et al (2005) argue, design requirements for a primary school as more than provision of well lit cheery class rooms. Designers must look into ancillary areas (such as toilets, play areas, dinning/ eating areas and extra curricular activities). There are also several design features discussed by Pere and Capeluto (2009) that are now being considered as important contributors towards better school performance for children and a sense of well being on the part of students, teachers and staff. These features include day lighting, acoustics, air quality, thermal comfort, attention to materials, and incorporation of natural elements such as trees, plants and landscaping (Orenshall, 2009).

The current research has an exploratory approach to evaluate environmental aspects of primary schools in a particular urban environment of Islamabad and investigate occupant's perceptions and behavior with reference to school buildings. As the urban population has increased manifolds and number of students in public schools has increased as well, therefore, to cater the needs of growing children, the provision of such facilities has to be re-established. The study is limited to evaluate the prevailing environmental conditions including light, acoustics, air movement, thermal comfort and space distribution in the existing schools. The values of these aspects are measured by the study of different design variables including orientation, openings, room size and other structural details as well as space allocated for different purposes. The objectives are to evaluate the existing physical conditions in the selected case studies according to international standards and thereby selecting the lowest rated school building for remodeling. The study is concluded with proposals for remodeling of existing primary schools securing favorable environment for children.

\section{PUBLIC SCHOOL BUILDINGS IN ISLAMABAD}

Schools in Pakistan are run both by public and private sector. The public schools are established to provide low cost education to masses. The private schools on the other hand are driven purely by commercial considerations. The private schools are not included in the scope of this study because the buildings of high cost school systems are usually designed according to the school system's standards and appear to meet most of the basic needs. On the other hand, the medium and low cost private schools are usually housed temporarily in the make-shift rented residential accommodations which are not designed to serve the purpose of a school building.
The public schools, however, have the advantage of having their own dedicated buildings on large pieces of land which, despite scarcity of funds, allow the authorities to augment and expand the building accommodation to meet the growing demand. But often, these expansions and augmentations are compromised on quality and design of the building due to various constraints and pressures. The incumbent study therefore focuses on public schools because of their ownership advantage over private schools and the fact that any reorganization or modification could result in permanent impact and also has the potential for replication at other similar places.

Most of the public school buildings in Islamabad are 30 35 years old, and are based on the then assessed needs of population, prevailing building construction design and technology and academic systems [Figure-1]. However, the population of the city has now increased manifolds and the number of students in public schools has obviously increased as well. Currently, there are two types of public schools running in Islamabad including Model schools of Islamabad and Federal Government Schools of Islamabad operating in each sector of the city. Model Schools start from Grade 1 to Grade 10. They have adequate site area with proper school building and serve separately for girls and boys. The Federal Government Junior Model Schools cater Grade 1 to Grade 5. Federal Government Schools provide primary level education to large chunk of the local population. These however, are established in designed school buildings at adequate site area but evaluation and monitoring of these buildings suggests that they suffer from multiple environmental deficiencies and lack in providing favourable environment for children.

Subsequently, the study has highlighted the need and requirement for additional class rooms and allied facilities such as toilets, cafeteria, art rooms, in-house dispensary,

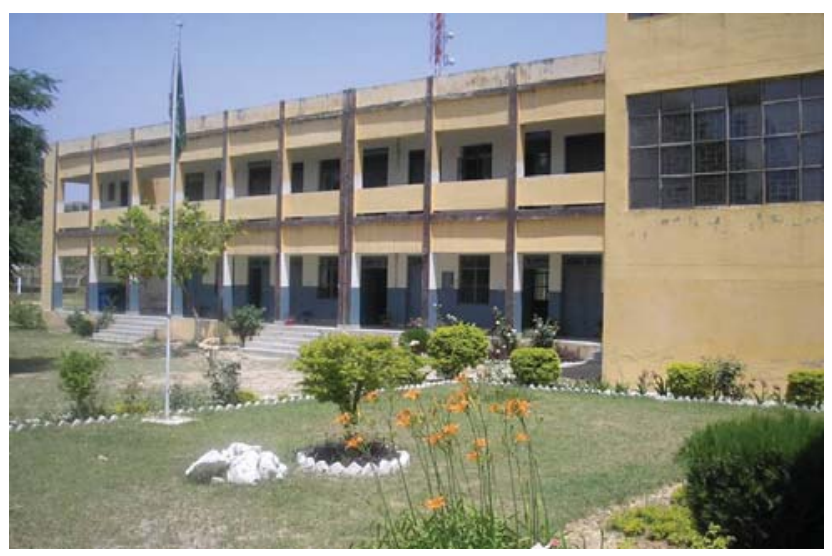

Figure-1: Federal Government School of Islamabad. 
staff room, etc. Furthermore, introduction of new technologies such as computers and audio-video facilities makes it all the more important that they be made a part of the educational institution so that students can be at par with those students who are studying in the private schools and are well-versed with the advancements taking place at a national as well as global level. For all these additional needs spaces are to be allocated in future school designs [Figure-2]. In addition to this, appropriate sized play grounds with play items, gymnasium, and swimming pools (where appropriate) need to be added for the physical growth of children. Given all the financial and space constraints, it may be difficult to completely reconstruct an existing school. However, an effort could be made to modify it to the possible extent on the basis of available resources through reconfiguration, reorganization and augmentation/ expansion of the school's existing buildings to provide modern academic facilities as well as making it more environment and user friendly. Furthermore, public schools are large in number and follow a standard design pattern and therefore appropriate design recommendations can be replicated at other similar sites.

\section{SCHOOL BUILDING MONITORING AND EVALUATION TECHNIQUES}

Monitoring activities may commence from the design stage of a primary school building continuing to its performance up to full satisfaction of the users and the management. According to Langston (2001) monitoring can be described as the record of actual building performance of a particular project in a form that facilitates subsequent life cost planning and management activities. Post occupancy evaluation ${ }^{1}$ (POE) technique has been adopted to evaluate the current schools' conditions. POE assesses how well buildings match users' needs, and identifies ways to improve building design, performance and fitness for purpose. Preiser and Vischer (2005) argued that the accommodation and activities of primary school buildings need to be examined in order to assess the full utilization of the provision made within the resource limits. The evaluation of school buildings may be seen with respect to building performance, users' satisfaction, management satisfaction as well as cost effectiveness (Sanoff, 2001). POE for particular situation of school environment is a short term process that seeks to identify major success and failures. The findings describe and explain the performance of the school building and after extensive

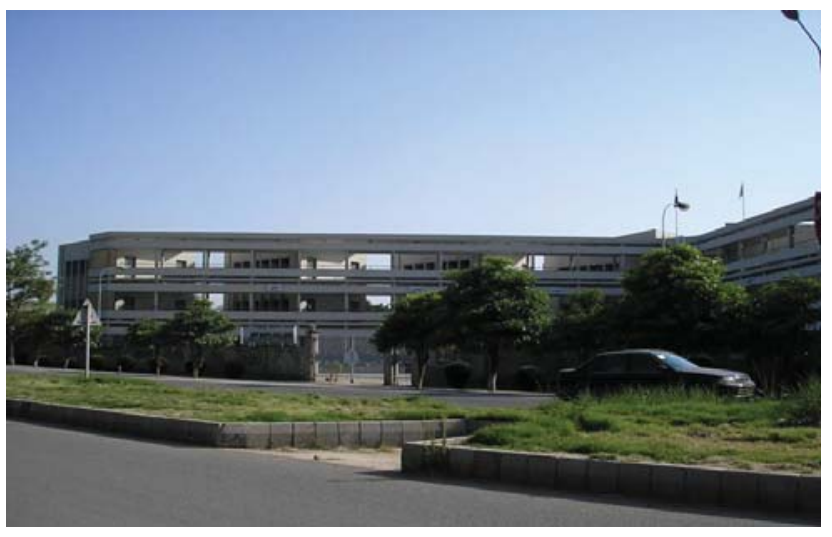

Figure-2: A High Cost Private School of Islamabad.

findings, a recommendation for future takes place (HEFCE, 2006). Analysis can be drawn based on typical data collection which may lead to redesigning or remodeling of existing primary schools. A perfect use of primary school building accommodation is of prime importance in order to gain cost effectiveness. The school building performance on the basis of energy conservation measures is also to be considered (Milla \& Pattison, 2003). Baird et al (1996) also concluded the optimum consumption of power and gas during working hours has to be given prime attention in order to make the facility cost efficient.

\section{COMPARATIVE ANALYSIS OF ENVIRONMENTAL STANDARDS}

Ministry of Housing and Works, Environment and Urban Affairs Division has prescribed a National Reference Manual on Planning and Infrastructure Standards as the 'National Standards' (PEPEC, 1986) that covers standards for all types of public buildings in Pakistan including primary schools. However, the prevailing international standards such as Time Saver Standard (TSS) (Chiara \& Crosbie, 2001) and UNESCO Standards (UNESCO, 1969) also need to be reviewed to determine the adequacy of the primary school building requirements to a wider range. These standards do not provide same parameters for their application and can serve the purpose of guidelines only, while actual design parameters have to be determined in accordance with local climate and general environment of the region. For example TSS highlighted to improve the health and academic levels of young children for securing appropriate school

1 Post Occupancy Evaluation involves systematic evaluation of opinion about buildings in use, from the perspective of the people who use them. 
environment through maximizing daylight and use of vibrant colors to provide psychological aid to learning, whereas, UNESCO emphasizes on bilateral light in classroom with windows up to ceiling height and shady trees outside to avoid glare. National Standards prefer the north-south orientation of classrooms to reduce solar glare. The acoustical conditions set out by TSS are based on circumstances of listener and suggest absorbing materials in corridors, whereas UNESCO and National Standards do not provide such details in this context. Thus, it is proposed to consult the international standards/guidelines where national standards are not available and adapt them for local needs. Table 1 shows the general applicable standards of relevant parameters.

\section{RESEARCH DESIGN/ METHODOLOGY}

Research has taken such conditions that are unavoidable for promoting a learning environment and physical development for the growing school children. All aspects and variables are interrelated. A figurative expression of the relationship of various aspects and variables undertaken for research is shown in [Figure-3].

\subsection{Sampling}

Population of study comprised of all the Federal Government Primary Schools of Islamabad. Random Stratified Sampling Technique has been adopted using Descriptive Survey to establish the basis of the study. Most of the schools under the Federal Directorate of Education (FDE) are built on similar pattern in terms of building materials, construction techniques, land size, layout and internal facilities. The research was designed to thoroughly investigate the buildings' design, its prevailing conditions, classrooms, and physical facilities for students, teachers and supporting staff. The research required significant time, along with monitory and logistical resources to accomplish the survey and generate remodeling proposal for each of its surveyed sample. Since the research was not funded externally, it was not possible to extend it to a large sample of schools. Therefore, the scope of the study was kept limited to 5 case studies of schools and one remodeling proposal. The sample was restricted to the public schools operating under FDE and the sample drawn comprised of one school each from five different residential sectors of the city depicting different economic levels.

\begin{tabular}{|c|c|c|}
\hline S.No. & \multicolumn{2}{|c|}{ Standard (TSS) } \\
\hline & Space required per student in classroom & $1.2 \mathrm{~m}^{2}$ to $2.5 \mathrm{~m}^{2}$ \\
\hline & Overall classroom size & $2.6 \mathrm{~m}^{2}$ to $3.5 \mathrm{~m}^{2}$ \\
\hline & Space for art and craft and other activities & $5 \mathrm{~m}^{2}$ \\
\hline & Multipurpose hall accommodation & 300 to 600 students \\
\hline & \multicolumn{2}{|c|}{ Standard (UNESCO) } \\
\hline & Desirable space for 25 students & $6,070 \mathrm{~m}^{2}$ \\
\hline & Space for play area and academic activities & $3.5 \mathrm{~m}^{2}$ \\
\hline & Minimum space required per pupil in classroom & $0.93 \mathrm{~m}^{2}$ to $1.4 \mathrm{~m}^{2}$ \\
\hline & Classroom ceiling height & $3.05 \mathrm{~m}$ \\
\hline & Illumination standard & 107.64 Lux \\
\hline & Ceiling and Walls color & Very light \\
\hline & 1 W.C. & 50 boys \\
\hline & 1 Urinal & 30 boys \\
\hline & $1 \mathrm{~W} . \mathrm{C}$. & 25 girls \\
\hline & 1hand wash facility & 25 pupil \\
\hline & \multicolumn{2}{|c|}{ Standard (National Standards) } \\
\hline & Primary school plot size & $0.6-1.0$ hectares \\
\hline & Minimum tolerable site area & $7.5 \mathrm{~m}^{2}$ per pupil in existing building \\
\hline & Minimum tolerable site area & $10 \mathrm{~m}^{2}$ per pupil in new building \\
\hline & Number of students in single stream school & 25 \\
\hline & Number of students in five streams & 50 \\
\hline & Size of classroom & $54 \mathrm{~m}^{2}$ \\
\hline & Space per student & $1.1 \mathrm{~m}^{2}$ \\
\hline & Area for other curricular activities & $1.1 \mathrm{~m}^{2}$ \\
\hline & Number of washrooms for 125 students & 2 \\
\hline & Number of washrooms for 600 students & 8 \\
\hline & Number of washrooms for 1250 students & 10 \\
\hline & Recommended play field area & $2.5 \mathrm{~m}^{2}$ to $5.4 \mathrm{~m}^{2}$ per student \\
\hline
\end{tabular}

Table-1: General Applicable Standards of Relevant Parameters. 


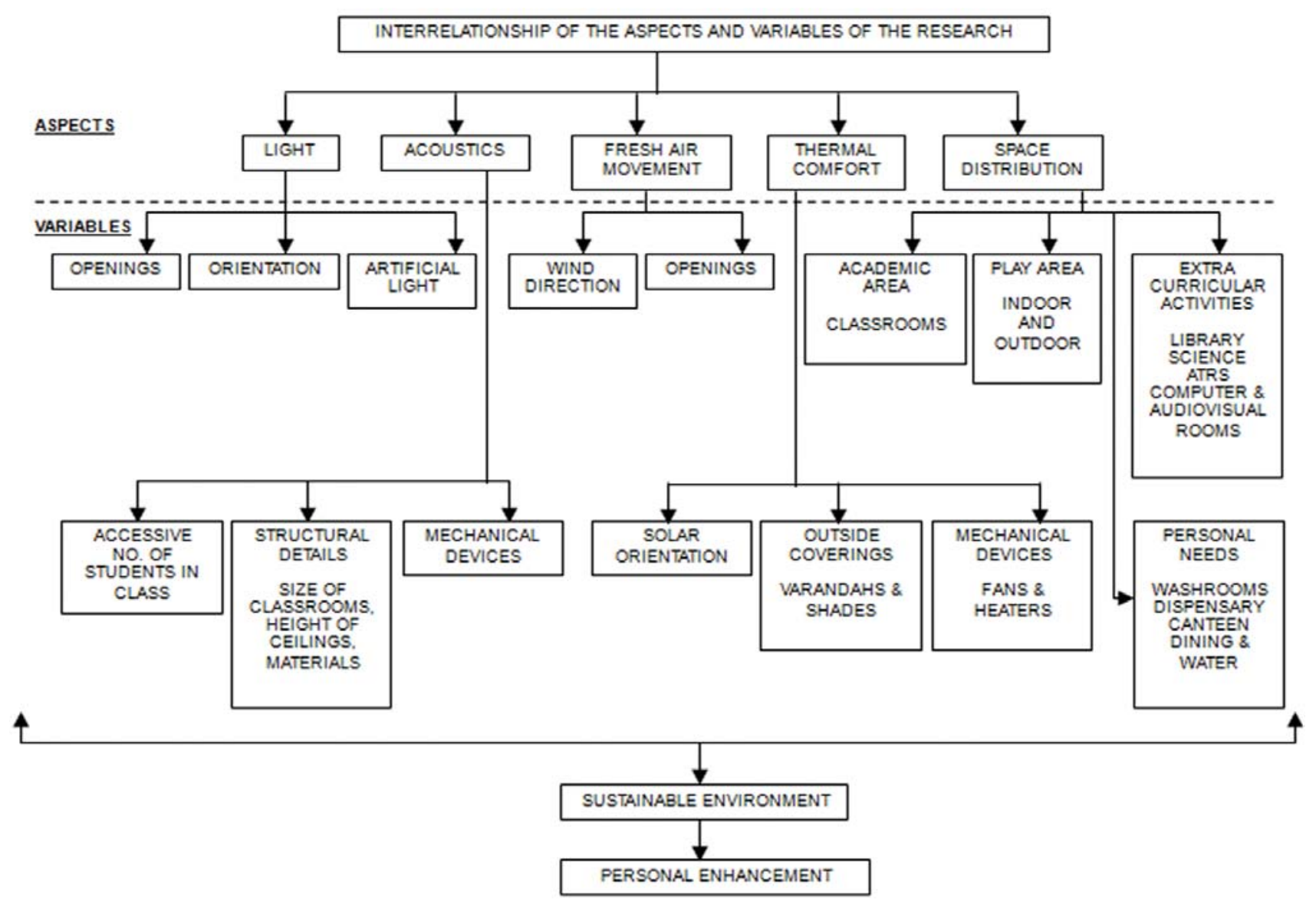

Figure-3: Graphical representation of interrelationship of the aspects and variables of research.

\subsection{Procedure Of Study}

According to PPRC (2004) recommendation for sustainable designs for schools, it has been outlined that optimal learning environment includes lighting, thermal comfort, adequate ambiance, noise control provision and physical facilities which directly help students to enjoy the learning process as well as help teachers to optimize teaching methods. Since no earlier study was available on school environments in Pakistan, a pilot study was carried out at ten schools in Islamabad and its periphery (semi urban). The pilot study was aimed at determining the types of schools to be studied and also to focus on environmental variables that may be negatively responded by students and teachers. The results of piloting lead to the decision of selecting the FG Schools in main sectors of Islamabad city for the reasons elaborated in section 2. The selection of environmental variables was based on five major aspects (light, acoustics, fresh air movement, thermal comfort and flaws in space distribution) studied in 10 schools selected for piloting. To assess the needs of the real users comprising of school staff and students, two questionnaires based survey forms were designed and the feedback of 10 staff members and 30 students from each school was sought. Questionnaires were designed on the basis of user's perceptions and behaviors studied earlier by built environment researchers (Zhang, Y. 2010). Students of classes four and five were included in the study sample and questions were designed considering the age of students. The questionnaires were also pretested before the actual survey. In addition, an observation sheet was filled by the researchers for each school for evaluation of building layout and design, and environmental features of the selected schools. The building with maximum deficiencies and gaps was selected for the remodeling proposal. Primarily, the TSS, and where required National Reference Manual on Planning and Infrastructure Standards, were used for the purpose of remodeling of the selected building. A comparative matrix was prepared to demonstrate the deficiencies and gaps in the existing building design and layout. A detailed revised plan of the parts of 
building was also prepared to elaborate the remodeling proposal.

\subsection{Research Instruments}

Four types of tools were applied for the purpose of data collection:

- An Observation Sheet comprising a checklist was used for the evaluation of school buildings to determine the user-friendliness. (Survey Form - 1)

- Two Questionnaires, one for the students and the other for the teaching staff were used to find out user satisfaction. (Survey Form - 2)

- Photographs were taken and lay out plans of the five selected schools were acquired to assess the existing building conditions.

- Physical Surveys were conducted with the help of environmental meters for the assessment of classrooms.

\section{SURVEY FORM - 1}

A checklist in the observation sheet.

\begin{tabular}{|l|l|}
\hline 1 & Name of the School \\
\hline 2 & Location \\
\hline 4 & Medium of Instructions \\
\hline 3 & Gender \\
\hline 4 & Total number of students \\
\hline 5 & Total number of teachers \\
\hline 6 & Total number of support staff \\
\hline 7 & Number of streams per class \\
\hline 8 & Average number of students per class \\
\hline 9 & Site Area (m ${ }^{2}$ ) \\
\hline 10 & Space distribution ( ${ }^{2}$ ) \\
\hline 11 & Type of building \\
\hline 12 & Academic space \\
\hline 13 & Ancillary space details \\
\hline 14 & Play areas \\
\hline 15 & Unused area \\
\hline 16 & Parking lot of school \\
\hline 17 & Condition of building \\
\hline 18 & Byelaws covering earthquake hazards \\
\hline 19 & $\begin{array}{l}\text { Byelaws covering fire hazards and } \\
\text { alternate provision of staircase in case of emergency }\end{array}$ \\
\hline 20 & $\begin{array}{l}\text { Environmental factors } \\
\text { a. School building orientation } \\
\text { b. Thermal Comfort }\end{array}$ \\
\hline
\end{tabular}

\section{CASE STUDIES}

Besides a large number of privately owned primary schools, Islamabad has a total of 64 federally administrated primary schools located in various sectors. By adopting Random Stratified Sampling, five schools had been selected from different sectors as case studies. A detailed survey and data analysis of various environmental conditions has been carried out for the following selected schools:

1. Federal Government Junior Model School F-7/2 [case study-1 plans]

2. Federal Government Junior Model School F- $8 / 2$ [case study-2 plans]

SURVEY FORM - 2 (Information gatthering from the teaching staff)

\begin{tabular}{|l|l|}
\hline 1 & Class room grade \\
\hline 2 & $\begin{array}{l}\text { Status of the teacher } \\
\text { School Administrator Class In charge Any other }\end{array}$ \\
\hline 3 & Qualification \\
\hline 4 & Attitude towards environmental comforts \\
a. & Light conditions in the class rooms \\
b. & Ventilation conditions in the class rooms \\
c. & Thermal comfort (temperatures) in the class rooms \\
d. & Audiovisual learning \\
e. & Wash rooms \\
f. & Play ground \\
g. & Cafeteria \\
h. & Safety and convenience \\
i) & What do you think about the step rise of the \\
& staircase(s) with respect to students? \\
& What do you think about the slope of ramp(s) with \\
j) & respect to students? \\
\hline
\end{tabular}

SURVEY FORM - 2 (Information gatthering from the teaching students)

\begin{tabular}{|l|l|}
\hline 1 & Class room grade \\
\hline 2 & Age group of the parents \\
\hline 3 & Qualification of the parents (highest amongst the two) \\
\hline 4 & Attitude towards environmental comforts: \\
a. & Light conditions in the class rooms \\
b. & Ventilation conditions in the class rooms \\
c. & Thermal comfort (temperatures) in the class rooms \\
d. & Audiovisual learning \\
e. & Wash Rooms \\
f. & Play Ground \\
g. & Cafeteria \\
h. & Safety and convenience \\
i) & What do you think about the slope of ramp(s) with \\
j). & respect to students? \\
\hline
\end{tabular}




\begin{tabular}{|c|c|c|c|c|c|}
\hline Basic Information & $\begin{array}{l}\text { F.G. JMS } \\
\text { F-7/2 }\end{array}$ & $\begin{array}{l}\text { F.G. JMS } \\
\text { F-8/2 }\end{array}$ & $\begin{array}{l}\text { F.G. JMS } \\
\text { I-8/1 }\end{array}$ & $\begin{array}{l}\text { F.G. JMS } \\
\text { E-7 }\end{array}$ & $\begin{array}{l}\text { F.G. JMS } \\
\text { G-9/2 }\end{array}$ \\
\hline Year of Construction & 1977 & 1983 & 1987 & 1987 & 2000 \\
\hline Type of Building & Double Storied & Single Storied & Double Storied & Double Storied & Double Storied \\
\hline Site Area $\left(\mathrm{m}^{2}\right)$ & 9,510 & 5,974 & 3,901 & 7,647 & 7,426 \\
\hline No. of Students & 384 & 145 & 905 & 94 & 347 \\
\hline No. of Teachers & 13 & 7 & 33 & 6 & 12 \\
\hline No. of Support Staff & 5 & 7 & 7 & 7 & 9 \\
\hline No. of Streams per class & 2 & 1 & 4 & 1 & 2 \\
\hline $\begin{array}{c}\text { Average number of students/ } \\
\text { class }\end{array}$ & 40 & $30-35$ & 50 & 14 & $40-45$ \\
\hline Academic Area $\left(\mathrm{m}^{2}\right)$ & 469 & 204 & 852 & 207 & 375 \\
\hline Play Area $\left(\mathrm{m}^{2}\right)$ & 7,340 & 4,602 & 1,244 & 5,221 & 4,639 \\
\hline Ancillary Area $\left(\mathrm{m}^{2}\right)$ & 406 & 355 & 1,586 & 484 & 152 \\
\hline
\end{tabular}

Table-2: Basic information about school buildings.

3. Federal Government Junior Model School I-8/1 [case study-3 plans]

4. Federal Government Junior Model School E-7 [case study-4 plans]

5. Federal Government Junior Model School G-9/2 [case study-5 plans]

The primary school buildings under this study comprise of a good blend with respect to their age, type and size of buildings. The school buildings show a wide disparity between their site areas and uneven space distribution was also observed for academic, playing as well as ancillary usage. As a consequence, the rear boundary walls are either non-existent or insufficient which increases the danger of wild animals entering the premises. [Table-2] shows a compact description of the conditions in school buildings.

\section{FINDINGS}

\subsection{Space Distribution}

Table-3 presents the distribution of spaces in school buildings. The average academic space per student provided in the buildings differs in each school and it is found below the standards. The classroom size is insufficient (F.G. JMS G9/2) for present number of students per class [Figure-4]. Average class strength is much higher than the standard strength i.e. 20-25 students. The building plan in F.G. JMS F-7/2 appears inconsistent with respect to the available site area. Ratio between open space and built up space is inconsistent as few classrooms are built on ample ground space. The spaces provided for outdoor games and physical activities are also observed inappropriate. Open area provided for such activity is least in F.G. JMS I-8/1 i.e.14\%. None of these schools have properly maintained play ground nor developed space to contain play items. Provision of ancillary

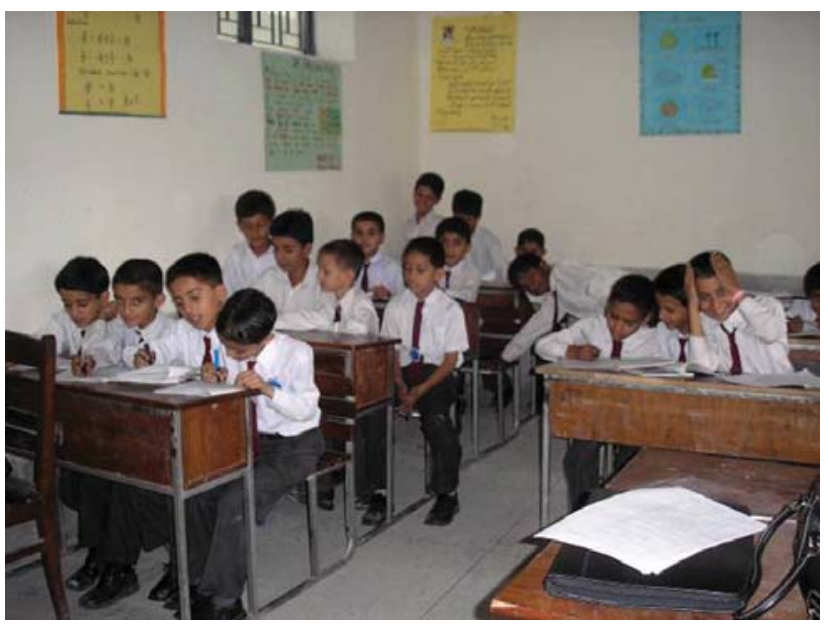

Figure-4: Distribution of Academic Space in F.G. JMS G-9/2.

spaces is also insufficient. No concept of multipurpose hall was observed except in F.G. JMS I-8/1. The staffroom facility also does not seem to be suitably provided as per social and psychological requirements recommended in studies of environmental quality considering socio-psychological aspects in buildings. These indicators reflect inadequate environmental quality in most schools.

\subsection{Environemntal Considerations}

The aspects of environmental quality measured in the present research include light, acoustics, fresh air movement and thermal comfort. Light meter (Model: LX-1102) is used to measure the light and sound level meter (TENMARKS Sound Level Meter, Model: TM-101) is used to measure the noise level in class rooms. The detail is provided in 


\begin{tabular}{|c|c|c|c|c|c|c|}
\hline Spaces & Space distribution & $\begin{array}{c}\text { F.G. JMS } \\
\text { F-7/2 }\end{array}$ & $\begin{array}{c}\text { F.G. JMS } \\
\text { F-8/2 }\end{array}$ & $\begin{array}{c}\text { F.G. JMS } \\
\text { I-8/1 }\end{array}$ & $\begin{array}{c}\text { F.G. JMS } \\
\text { E-7 }\end{array}$ & $\begin{array}{c}\text { F.G. JMS } \\
\text { G-9/2 }\end{array}$ \\
\hline \multirow{5}{*}{$\begin{array}{c}\text { Academic space } \\
\text { distribution }\end{array}$} & No. of classrooms & 11 & 5 & 20 & 5 & 10 \\
\hline & Area of classrooms $\left(\mathrm{m}^{2}\right)$ & 43 & 41 & 43 & 41 & 37 \\
\hline & No. of labs & - & - & - & - & - \\
\hline & Avg. no. of student/ class & 40 & $30-35$ & 50 & 14 & $40-45$ \\
\hline & Academic space/ student $\left(\mathrm{m}^{2}\right)$ & 1.08 & 1.17 & 0.86 & 2.93 & 0.82 \\
\hline \multirow{2}{*}{$\begin{array}{c}\text { Play area } \\
\text { distribution }\end{array}$} & Play areas size & $48 \%$ & $70 \%$ & $14 \%$ & $92 \%$ & $28 \%$ \\
\hline & Play items & $8 \%$ & $16 \%$ & $18 \%$ & $17 \%$ & $5 \%$ \\
\hline \multirow{12}{*}{$\begin{array}{l}\text { Ancillary } \\
\text { facilities }\end{array}$} & Multipurpose hall & - & - & 1 & - & - \\
\hline & No. of washrooms & 4 & 4 & 8 & 4 & 10 \\
\hline & Staff room & 1 & 1 & 1 & - & 1 \\
\hline & Storage room & 1 & - & - & 2 & 1 \\
\hline & Cafeteria & 1 & 1 & - & - & - \\
\hline & Dining hall & - & - & - & - & - \\
\hline & Corridors & 2 & 2 & 6 & 2 & 4 \\
\hline & Open assembly area & 1 & 1 & - & 1 & - \\
\hline & Staff quarter & 1 & 1 & - & 1 & - \\
\hline & Guard cabin & 1 & - & - & 1 & - \\
\hline & Parking area & Inside & Outside & Outside & Outside & Outside \\
\hline & Lawn & - & 1 & 2 & & \\
\hline
\end{tabular}

Table-3: Space Distribution

\begin{tabular}{|c|c|c|c|c|c|c|c|c|c|c|c|c|c|c|c|}
\hline \multirow{3}{*}{ 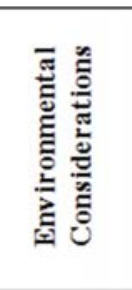 } & \multicolumn{5}{|c|}{ Light adequacy } & \multirow{2}{*}{\multicolumn{2}{|c|}{$\begin{array}{c}\text { Acoustics } \\
\text { Noise level dB } \\
\text { (A) }\end{array}$}} & \multicolumn{4}{|c|}{$\begin{array}{c}\text { Ventilation and Air } \\
\text { movement adequacy }\end{array}$} & \multicolumn{4}{|c|}{ Thermal Comfort } \\
\hline & \multirow{2}{*}{$\begin{array}{c}\text { Light } \\
\text { meter } \\
\text { reading } \\
(\text { LUX) } \\
\end{array}$} & \multicolumn{2}{|c|}{$\begin{array}{c}\text { Day light } \\
(\%)\end{array}$} & \multicolumn{2}{|c|}{$\begin{array}{c}\text { Artificial } \\
\text { light } \\
(\%)\end{array}$} & & & \multicolumn{2}{|c|}{$\begin{array}{c}\text { Ventilation } \\
(\%)\end{array}$} & \multicolumn{2}{|c|}{$\begin{array}{c}\text { Air } \\
\text { movement } \\
(\%)\end{array}$} & \multicolumn{2}{|c|}{$\begin{array}{c}\text { Winter } \\
(\%)\end{array}$} & \multicolumn{2}{|c|}{$\begin{array}{c}\text { Summer } \\
(\%)\end{array}$} \\
\hline & & By & $\begin{array}{c}\text { By } \\
\text { S }\end{array}$ & $\stackrel{\text { By }}{\mathbf{T}}$ & $\begin{array}{c}\text { By } \\
\text { S }\end{array}$ & $\begin{array}{l}\text { classr } \\
\text { ooms }\end{array}$ & corridor & By & $\begin{array}{c}\text { By } \\
\text { S }\end{array}$ & $\begin{array}{c}\text { By } \\
\text { T }\end{array}$ & $\begin{array}{c}\text { By } \\
\mathrm{S}\end{array}$ & $\begin{array}{c}\text { By } \\
\text { T }\end{array}$ & $\begin{array}{c}\text { By } \\
\text { S }\end{array}$ & By & $\begin{array}{r}\text { By } \\
\text { S }\end{array}$ \\
\hline $\begin{array}{c}\text { F.G. JMS } \\
\text { F-7/2 }\end{array}$ & 340.9 & 90 & 87 & 100 & 80 & 82.9 & 69.7 & 100 & 97 & 100 & 100 & 80 & 67 & 80 & 20 \\
\hline $\begin{array}{c}\text { F.G JMS } \\
\text { F-8/2 }\end{array}$ & 360.7 & 86 & 100 & 86 & 97 & 74.2 & 63.3 & 43 & 47 & 43 & 30 & 57 & 80 & 57 & 50 \\
\hline $\begin{array}{c}\text { F.G. JMS } \\
\text { I-8/1 }\end{array}$ & 339.5 & 70 & 100 & 90 & 89 & 76.7 & 81.9 & 90 & 94 & 90 & 72 & 60 & 82 & 60 & 50 \\
\hline $\begin{array}{c}\text { F.G. JMS } \\
\text { E-7 }\end{array}$ & 401.8 & $\begin{array}{c}10 \\
0\end{array}$ & 100 & 86 & 41 & 71.9 & 71.4 & 86 & $\begin{array}{c}10 \\
0\end{array}$ & 86 & 100 & 57 & 100 & 100 & 41 \\
\hline $\begin{array}{l}\text { F.G. JMS } \\
\text { G-9/2 }\end{array}$ & 358.8 & 70 & 100 & 60 & 93 & 85.2 & 76.0 & 50 & $\begin{array}{c}10 \\
0\end{array}$ & 70 & 100 & 10 & 7 & 60 & 67 \\
\hline Average & & 83 & 97 & 84 & 80 & 76.4 & 71.6 & 74 & 88 & 78 & 80 & 53 & 67 & 71 & 46 \\
\hline
\end{tabular}

Table-4: Environmental Considerations (S; student, T; teachers).

[Table-3]. The minimum standard of light meter measurement is 200 Lux. The table shows the range between 300 to 400 Lux which shows that there is no problem with respect to light deficiency. However, uniform distribution of light is not ensured. The noise problem in the classrooms seems to be caused by three conditions including the number of students, size of the classrooms and poor quality of electric fixtures installed. The noise level of classrooms measured through sound level meter is about 82 to $85 \mathrm{~dB}(\mathrm{~A})$ against 40 to $50 \mathrm{~dB}(\mathrm{~A})$. As per users' perception the fresh air movement in the classrooms appears to be sufficient except in F.G. JMS G-9/2 and F-8/2 as indicated in [Table-4]. In
F.G. JMS F-8/2, bad smell was sensed, rising from an open waste drain adjacent to the building [Figure-5] whereas in F.G. JMS G-9/2, one side window openings make cross ventilation impossible [Figure-6]. Being located in cooler zone, Islamabad demands more attention to the thermal comfort during winter seasons because in peak summer season schools are generally having vacations. Generally, students and teachers showed their satisfaction with available heating facilities except in F.G. JMS G-9/2 where the heating facility is very limited. However, the existing system can be replaced by more safe and energy efficient heating system such as solar heaters and geysers. 


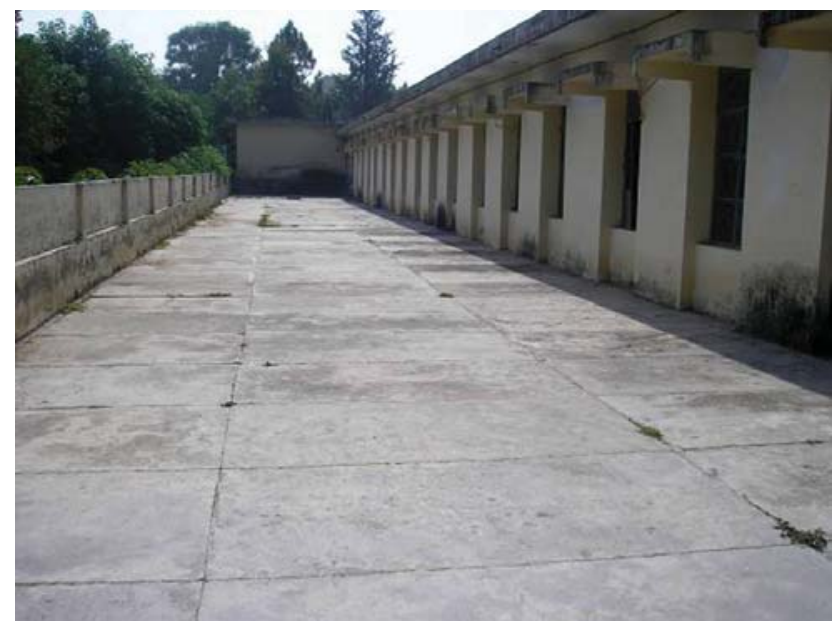

Figure-5: Open drain adjacent to the classrooms in F.G. JMS F-8/2.

\subsection{Facilities}

The various provisions made available to the staff and the students in the form of play area, play items, washrooms/person are inadequate (refer Table-1). While facilities such as dining space, cafeteria or dispensary are absent in all schools as shown in Table-5. In F.G. JMS F$7 / 2$ the play areas are not clearly marked and maintained [Figure-7]. Play area per student is $1.37 \mathrm{~m}^{2}$ instead of 3.5 $\mathrm{m}^{2}$ along with poor quality play items. Washroom provision has been made up to 96 and 113 students per washroom in F.G. JMS F-7/2 and I-8/1, instead of 25 students per washroom as shown in [Figure-8]. Unofficial canteens are being operated in few schools [Figure-9]. Mostly, schools do not offer safe drinking water and unhygienic contaminated tap water is the only choice for drinking except in two cases. (F.G. JMS F-7/2 and E-7 have provided filtered drinking water.)

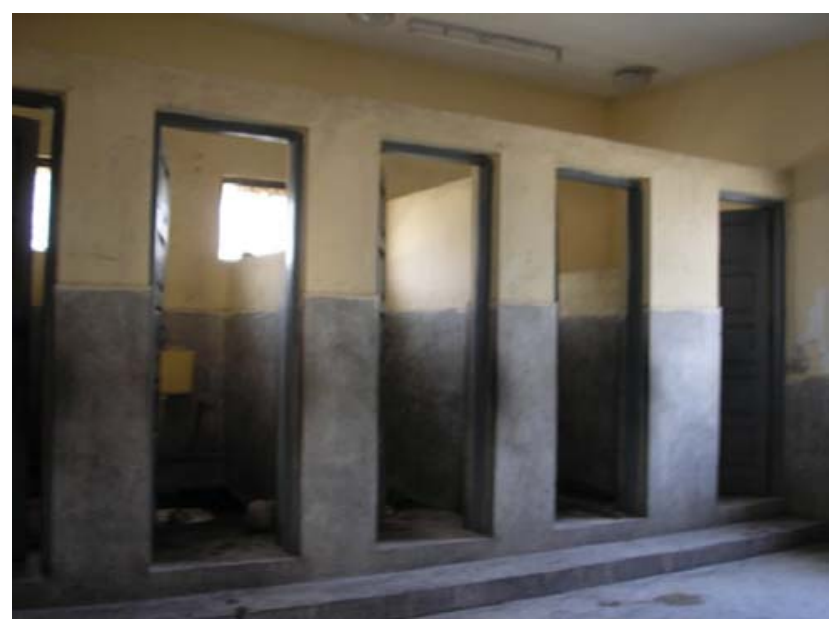

Figure-8: Inadequate washroom facility in F.G. JMS F-I-8/1.

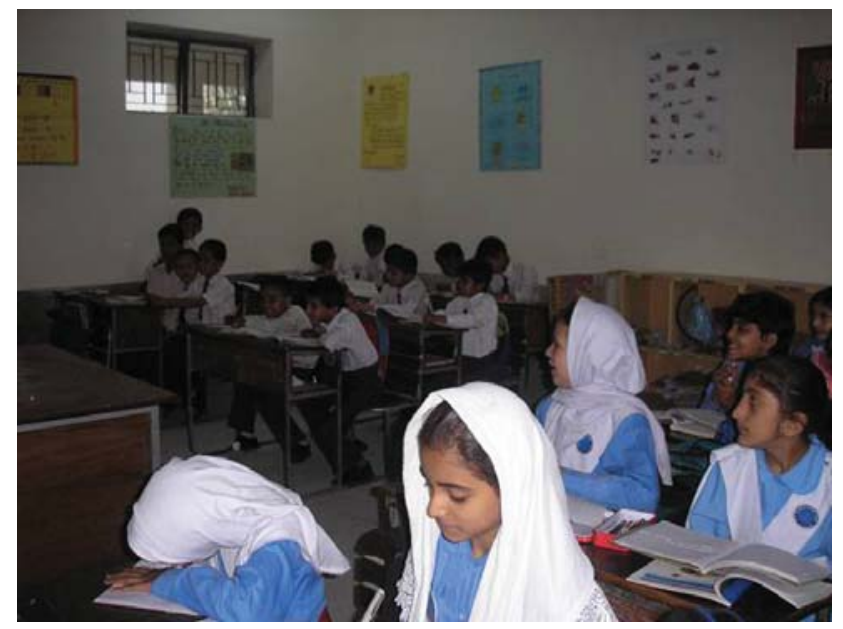

Figure-6: Inadequate ventilation in classroom in F.G. JMS F-8/2.

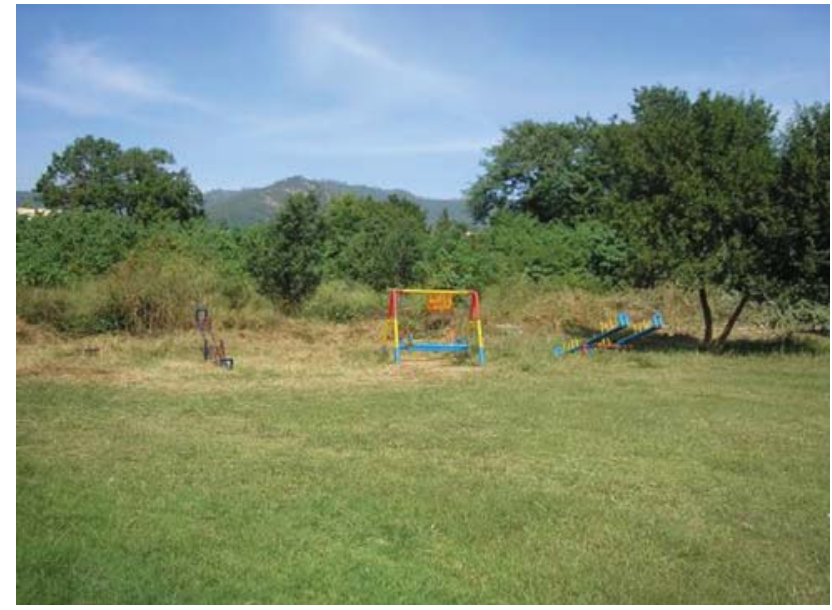

Figure-7: Un-marked play area in F.G. JMS F-7/2.

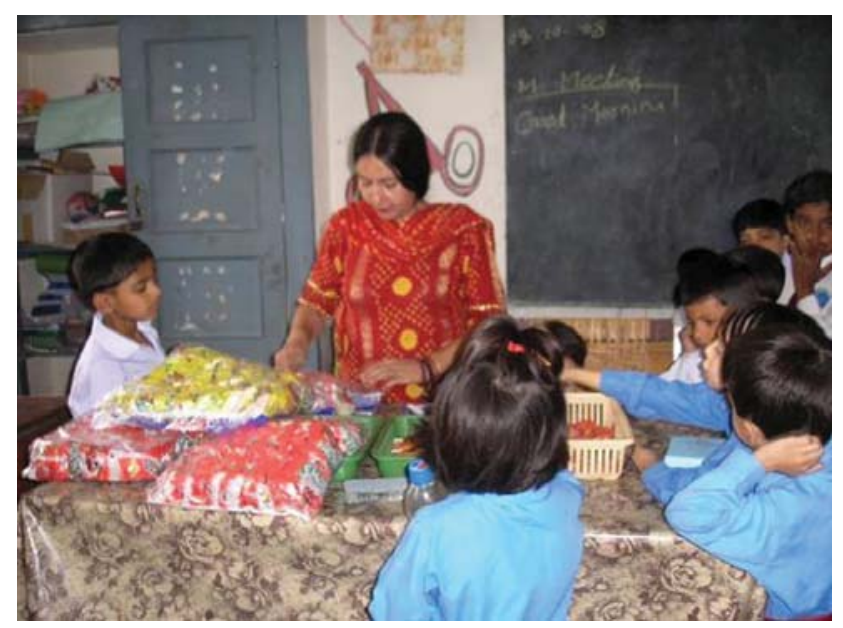

Figure-9: Un-official canteens in F.G. JMS G-9/2. 


\begin{tabular}{|c|c|c|c|c|c|c|c|c|c|c|c|c|c|c|c|}
\hline \multirow{3}{*}{ 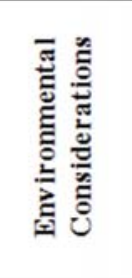 } & \multicolumn{5}{|c|}{ Light adequacy } & \multirow{2}{*}{\multicolumn{2}{|c|}{$\begin{array}{c}\text { Acoustics } \\
\text { Noise level dB } \\
\text { (A) }\end{array}$}} & \multicolumn{4}{|c|}{$\begin{array}{l}\text { Ventilation and Air } \\
\text { movement adequacy }\end{array}$} & \multicolumn{4}{|c|}{ Thermal Comfort } \\
\hline & \multirow{2}{*}{$\begin{array}{c}\text { Light } \\
\text { meter } \\
\text { reading } \\
(\text { LUX) }\end{array}$} & \multicolumn{2}{|c|}{$\begin{array}{c}\text { Day light } \\
(\%)\end{array}$} & \multicolumn{2}{|c|}{$\begin{array}{c}\text { Artificial } \\
\text { light } \\
(\%)\end{array}$} & & & \multicolumn{2}{|c|}{$\begin{array}{c}\text { Ventilation } \\
(\%)\end{array}$} & \multicolumn{2}{|c|}{$\begin{array}{c}\text { Air } \\
\text { movement } \\
(\%)\end{array}$} & \multicolumn{2}{|c|}{$\begin{array}{l}\text { Winter } \\
(\%)\end{array}$} & \multicolumn{2}{|c|}{$\begin{array}{c}\text { Summer } \\
(\%)\end{array}$} \\
\hline & & $\begin{array}{c}\text { By } \\
\text { T }\end{array}$ & $\begin{array}{c}\text { By } \\
\text { S }\end{array}$ & $\begin{array}{c}\text { By } \\
\text { T }\end{array}$ & $\begin{array}{c}\text { By } \\
\text { S }\end{array}$ & $\begin{array}{l}\text { classr } \\
\text { ooms }\end{array}$ & corridor & By & $\begin{array}{l}\text { By } \\
\mathrm{S}\end{array}$ & $\stackrel{\text { By }}{\text { T }}$ & $\begin{array}{c}\text { By } \\
\text { S }\end{array}$ & By & By & By & $\begin{array}{r}\text { By } \\
\text { S }\end{array}$ \\
\hline $\begin{array}{c}\text { F.G. JMS } \\
\text { F-7/2 }\end{array}$ & 340.9 & 90 & 87 & 100 & 80 & 82.9 & 69.7 & 100 & 97 & 100 & 100 & 80 & 67 & 80 & 20 \\
\hline $\begin{array}{c}\text { F.G. JMS } \\
\text { F-8/2 }\end{array}$ & 360.7 & 86 & 100 & 86 & 97 & 74.2 & 63.3 & 43 & 47 & 43 & 30 & 57 & 80 & 57 & 50 \\
\hline $\begin{array}{c}\text { F.G. JMS } \\
\text { I-8/1 }\end{array}$ & 339.5 & 70 & 100 & 90 & 89 & 76.7 & 81.9 & 90 & 94 & 90 & 72 & 60 & 82 & 60 & 50 \\
\hline $\begin{array}{l}\text { F.G. JMS } \\
\text { E-7 }\end{array}$ & 401.8 & $\begin{array}{c}10 \\
0\end{array}$ & 100 & 86 & 41 & 71.9 & 71.4 & 86 & $\begin{array}{c}10 \\
0\end{array}$ & 86 & 100 & 57 & 100 & 100 & 41 \\
\hline $\begin{array}{c}\text { F.G. JMS } \\
\text { G-9/2 }\end{array}$ & 358.8 & 70 & 100 & 60 & 93 & 85.2 & 76.0 & 50 & $\begin{array}{c}10 \\
0\end{array}$ & 70 & 100 & 10 & 7 & 60 & 67 \\
\hline Average & & 83 & 97 & 84 & 80 & 76.4 & 71.6 & 74 & 88 & 78 & 80 & 53 & 67 & 71 & 46 \\
\hline
\end{tabular}

* Safe drinking water (Filtered), ** Unsafe drinking water (Tap Water)

Table-5: Facilities and comfort (S; students, T; teachers).
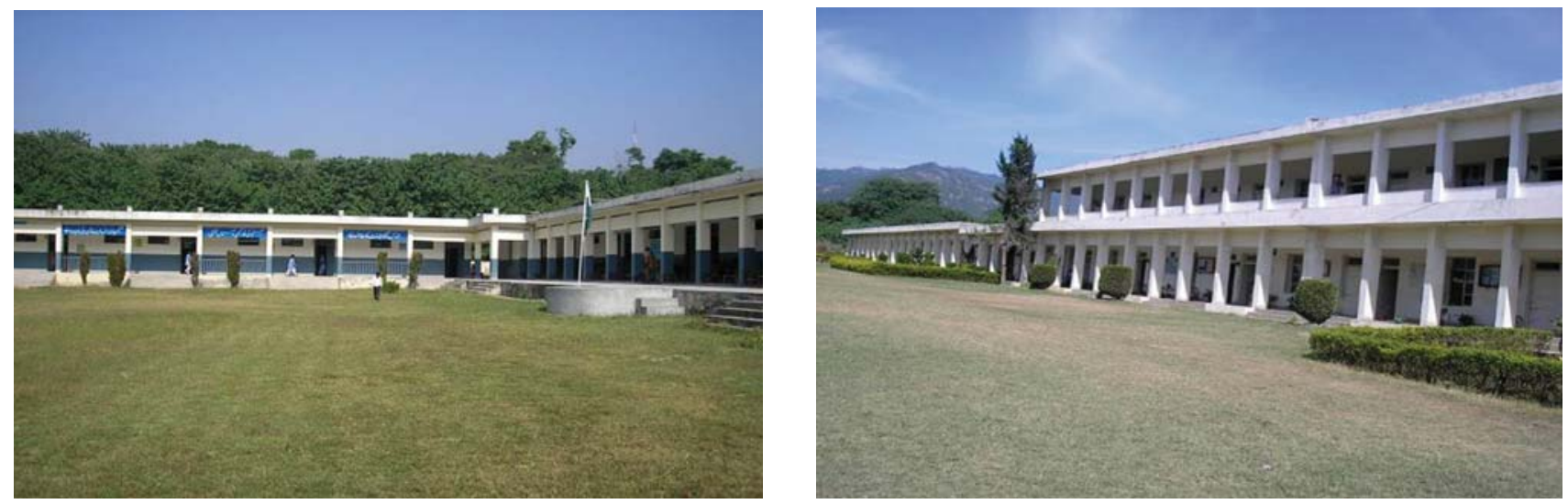

Figure-10: Well maintained condition of school buildings.

\subsection{Maintenance}

Table 6 shows the satisfaction of teachers and students with respect to maintenance of school buildings as shown in [Figure-10]. School management and staff seem generally satisfied except for the condition of washrooms that are highly neglected.

\subsection{Safety and Convenience}

Table-7 shows the opinion of teachers and students regarding safety and convenience. In F.G. JMS I-8/1 teachers and students complain about very narrow staircase. When staircase measured against the number of students and its

\begin{tabular}{|c|c|c|c|c|c|c|c|c|}
\hline \multirow{2}{*}{ Building Conditions } & \multicolumn{2}{|c|}{$\begin{array}{c}\text { Class rooms } \\
(\%)\end{array}$} & \multicolumn{2}{c|}{$\begin{array}{c}\text { Wash rooms } \\
(\%)\end{array}$} & \multicolumn{2}{c|}{ Ancillary spaces (\%) } & \multicolumn{2}{c|}{ Overall building condition (\%) } \\
\cline { 2 - 9 } & By T & By S & By T & By S & By T & By S & By T & By S \\
\hline F.G. JMS F-7/2 & 80 & 60 & 0 & 3 & 60 & 97 & 100 & 83 \\
\hline F.G. JMS F-8/2 & 100 & 100 & 71 & 50 & 100 & 93 & 100 & 97 \\
\hline F.G. JMS I-8/1 & 80 & 100 & 30 & 28 & 90 & 100 & 80 & 61 \\
\hline F.G. JMS E-7 & 100 & 100 & 43 & 59 & 100 & 100 & 100 & 94 \\
\hline F.G. JMS G-9/2 & 90 & 97 & 10 & 20 & 90 & 97 & 80 & 87 \\
\hline Average & 90 & 91 & 31 & 32 & 88 & 97 & 92 & 84 \\
\hline
\end{tabular}

Table-6: Maintenance of buildings (S; students, T; teachers). 


\begin{tabular}{|c|c|c|c|c|c|c|c|c|c|c|c|c|c|c|}
\hline \multirow{2}{*}{$\begin{array}{c}\text { Safety and } \\
\text { Convenience }\end{array}$} & \multicolumn{2}{|c|}{$\begin{array}{c}\text { Glass } \\
\text { material used }\end{array}$} & \multicolumn{2}{|c|}{$\begin{array}{c}\text { Height of } \\
\text { parapet wall }\end{array}$} & \multicolumn{2}{|c|}{$\begin{array}{c}\text { Height of } \\
\text { boundary } \\
\text { wall }\end{array}$} & \multicolumn{2}{|c|}{ Fire hazards } & \multicolumn{2}{|c|}{$\begin{array}{c}\text { Earthquake } \\
\text { hazards }\end{array}$} & \multicolumn{2}{|c|}{$\begin{array}{l}\text { Staircase } \\
\text { width }\end{array}$} & \multicolumn{2}{|c|}{$\begin{array}{l}\text { Height of } \\
\text { riser }\end{array}$} \\
\hline & By T & By S & By T & By S & $\begin{array}{l}\text { By } \\
\text { T }\end{array}$ & $\begin{array}{l}\text { By } \\
\text { S }\end{array}$ & By T & By S & By T & By S & By T & $\begin{array}{l}\text { By } \\
\text { S }\end{array}$ & By T & $\begin{array}{l}\text { By } \\
\text { S }\end{array}$ \\
\hline $\begin{array}{c}\text { F.G. JMS F- } \\
7 / 2\end{array}$ & $100 \%$ & $87 \%$ & $\begin{array}{l}\text { No } \\
\text { access }\end{array}$ & \begin{tabular}{|l|} 
No \\
access
\end{tabular} & $20 \%$ & $10 \%$ & $\begin{array}{l}\text { Non } \\
\text { existent }\end{array}$ & $\begin{array}{l}\text { Non } \\
\text { existent }\end{array}$ & $\begin{array}{l}\text { Non } \\
\text { existent }\end{array}$ & $\begin{array}{l}\text { Non } \\
\text { existent }\end{array}$ & $100 \%$ & $20 \%$ & $100 \%$ & $77 \%$ \\
\hline $\begin{array}{c}\text { F.G. JMS F- } \\
8 / 2\end{array}$ & $86 \%$ & $100 \%$ & $\begin{array}{l}\text { No } \\
\text { access }\end{array}$ & $\begin{array}{l}\text { No } \\
\text { access }\end{array}$ & $14 \%$ & $0 \%$ & $\begin{array}{l}\text { Non } \\
\text { existent }\end{array}$ & $\begin{array}{l}\text { Non } \\
\text { existent }\end{array}$ & $\begin{array}{l}\text { Non } \\
\text { existent }\end{array}$ & $\begin{array}{l}\text { Non } \\
\text { existent }\end{array}$ & N/A & N/A & N/A & N/A \\
\hline $\begin{array}{c}\text { F.G. JMS I- } \\
8 / 1\end{array}$ & $90 \%$ & $89 \%$ & $40 \%$ & $\begin{array}{l}\text { No } \\
\text { access }\end{array}$ & $60 \%$ & $0 \%$ & $\begin{array}{l}\text { Non } \\
\text { existent }\end{array}$ & $\begin{array}{l}\text { Non } \\
\text { existent }\end{array}$ & $\begin{array}{l}\text { Non } \\
\text { existent }\end{array}$ & $\begin{array}{l}\text { Non } \\
\text { existent }\end{array}$ & $40 \%$ & $0 \%$ & $100 \%$ & $80 \%$ \\
\hline F.G. JMS E-7 & $100 \%$ & $100 \%$ & $\begin{array}{l}\text { No } \\
\text { access }\end{array}$ & \begin{tabular}{|l|} 
No \\
access
\end{tabular} & $57 \%$ & $6 \%$ & $\begin{array}{l}\text { Non } \\
\text { existent }\end{array}$ & $\begin{array}{l}\text { Non } \\
\text { existent }\end{array}$ & $\begin{array}{l}\text { Non } \\
\text { existent }\end{array}$ & $\begin{array}{l}\text { Non } \\
\text { existent }\end{array}$ & N/A & N/A & N/A & N/A \\
\hline $\begin{array}{c}\text { F.G. JMS G- } \\
9 / 2\end{array}$ & $100 \%$ & $100 \%$ & $\begin{array}{l}\text { No } \\
\text { access }\end{array}$ & \begin{tabular}{|l} 
No \\
access
\end{tabular} & $20 \%$ & $3 \%$ & $\begin{array}{l}\text { Non } \\
\text { existent }\end{array}$ & $\begin{array}{l}\text { Non } \\
\text { existent }\end{array}$ & $\begin{array}{l}\text { Non } \\
\text { existent }\end{array}$ & $\begin{array}{l}\text { Non } \\
\text { existent }\end{array}$ & $10 \%$ & $0 \%$ & $70 \%$ & $93 \%$ \\
\hline Average & $95 \%$ & $95 \%$ & - & - & $34 \%$ & $4 \%$ & - & - & - & - & $50 \%$ & $7 \%$ & $90 \%$ & $83 \%$ \\
\hline
\end{tabular}

Table-7: Adequacy of safety and convenience of school buildings (S; students, T; teachers).

use at break-time and closing time it turned out to be less in width and confirmed user dissatisfaction [Figure-11]. In F.G. JMS G-9/2 the stairs towards the play area are unsafe [Figure-12]. General condition and height of boundary wall appears to be unsatisfactory as shown in [Figure-13]. No typical arrangement has been made so far to counter disaster situations.

\section{ANALYSIS}

Due to lack of funding and its appropriate utilization almost all public schools have no provision of designing new blocks or extension for any other facility. The provision to maintain the available facilities is also missing. The proper maintenance of the open spaces by plantation or proper landscaping is highly desirable to ensure more conducive environment. However, for maintenance of grassy play grounds, shady trees as well as floral plants, a regular watering system is

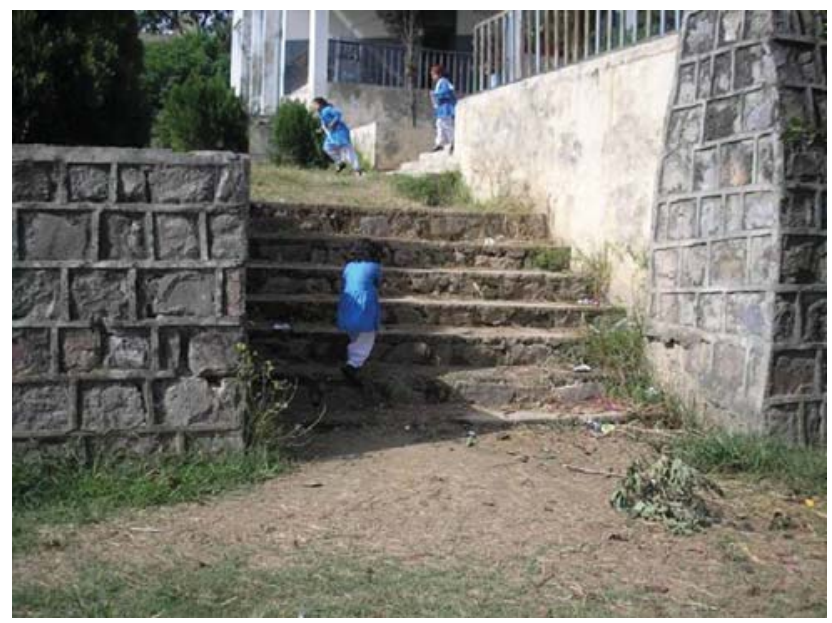

Figure-12: Unsafe stairs towards the play area F.G. JMS G-9/2.

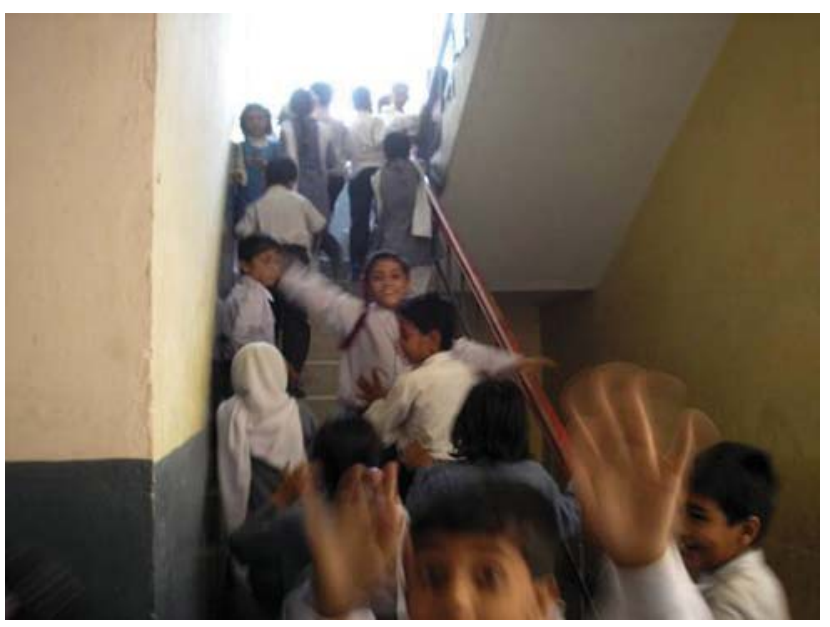

Figure-11: Insufficient width of staircase in F.G. JMS I-8/1.

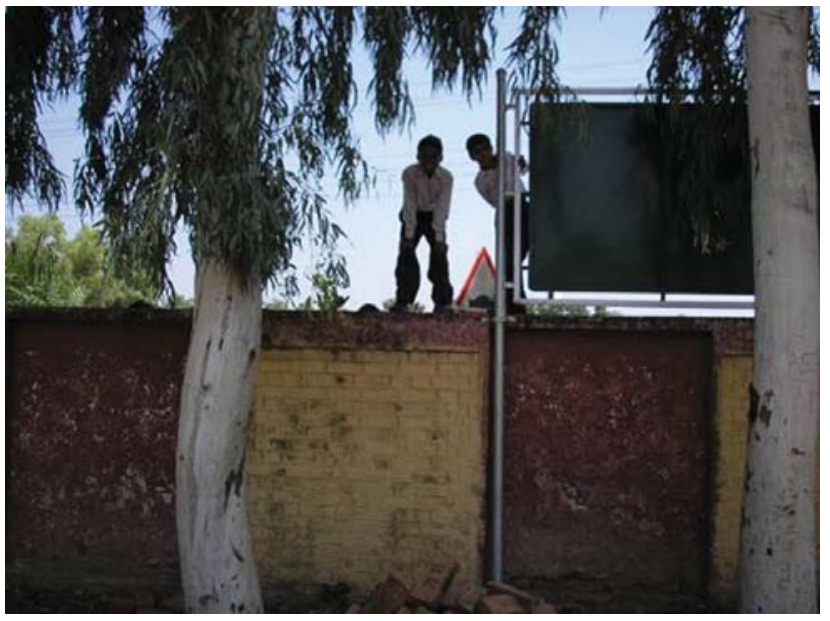

Figure-13: Insufficient height of boundary walls in F.G. JMS F-8/2 and F.G. JMS I-8/1. 


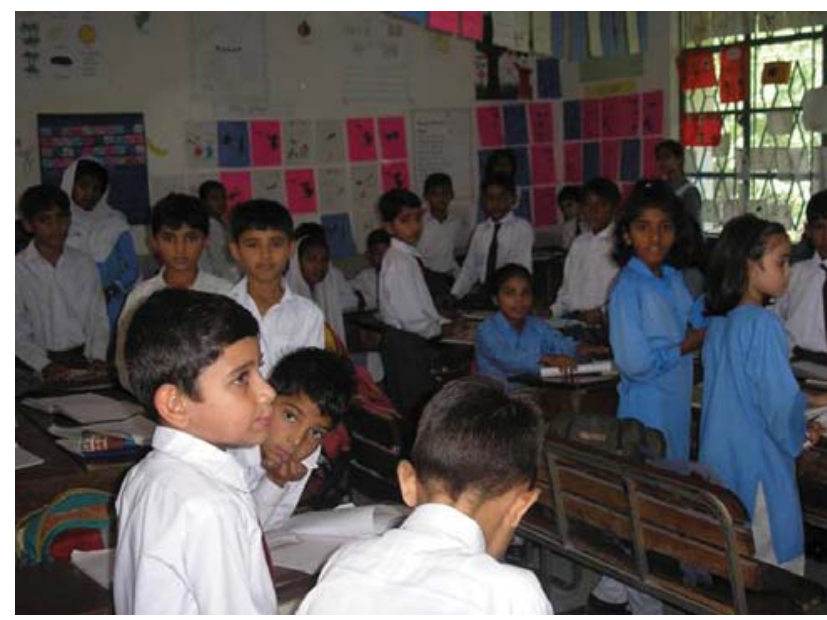

Figure-14: Lack of provision of daylight in F.G. JMS F-8/2.

desired. As there is a scarcity of water in water supply system in Islamabad; therefore there is a need to look for other alternates such as rainwater harvesting. Keeping in view the sudden variations in weather it seems quite essential that a multipurpose hall should be provided in each of these schools. There is no properly designed cafeteria or dining space observed in these schools along with no concept for provision of store room as the excessive material is observed dumped in washrooms. It is desirable to provide north daylight for classrooms. In F.G. JMS F-7/2, I-8/1 and E-7 adequate light is available whereas in F.G. JMS F-8/2 only six classrooms have this facility because of L- Shape setting of the building [Figure-14]. In F.G. JMS G-9/2 bilateral light is missing due to blocked north side as shown in [Figure-15]. There is a lack of community awareness for the provision of washrooms in regard to their number and location which is a significant factor for environmental conduciveness.

\subsection{Rationale for Remodeling}

The first phase of study pointed out the environmental problems in the selected schools of Islamabad. Comparative analysis of these results identified one of the schools (F.G. JMS G-9/2) having most environmental problems as explained in section 7.1 and 7.2. Hence, this school was chosen to propose the remodeling options at the second stage of research.

\subsection{Guidelines for Remodeling of the Existing Schools and Construction of New Buildings}

The extensive review of relevant literature as well as analysis of the survey data assembled in respect of five schools has facilitated to set out the following guidelines for the purpose

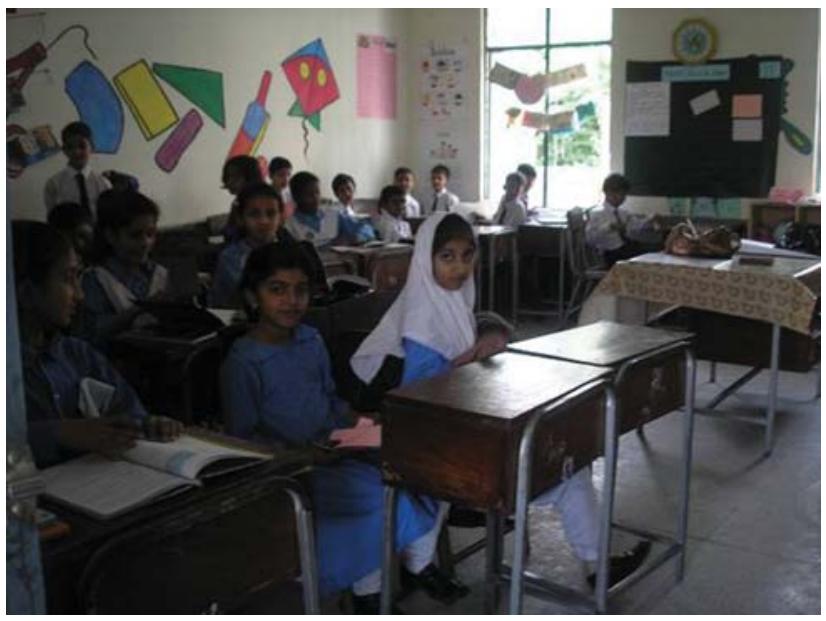

Figure-15: Non uniformity of light in classrooms of F.G. JMS G-9/2.

of development of new schools or remodeling the existing ones securing conducive environment for the children.

- The number of students per class should range between 25 to 35 students ensuring the provision of academic space at the rate of $1.2 \mathrm{~m}^{2}$ per student.

- The advisable number of stream per class is three.

- An overall play area recommended should be three times the covered area. The developed play space per student should be 3 to $3.5 \mathrm{~m}^{2}$.

- The play grounds should be properly oriented with respect to sun direction. A proper landscaping of all the open spaces around the school buildings must be made. Cafeteria and dining space for about 100 students at a time also needs to be properly located.

- Ideally, each school should have multipurpose hall, a library and a reading room.

- Owing to current education policies provision of additional space for science, computer, arts and audio visual aid laboratories also need to be considered.

- The admirable standard to be adopted for well maintained washrooms is 25 students per washroom.

- The condition of light particularly in the classrooms demands more attention. The bilateral window openings must be provided ensuring full penetration of north daylight at the height of student's desk level.

- All sorts of acoustical inconvenience particularly with 
respect to electric fixtures, excessive number of children as well as the type of building material used should be given due consideration to secure proper learning environment.

- $\quad$ Fresh air movement and ventilation are fundamental aspects of providing suitable classroom environment. Issues of suffocation and stuffiness in the classrooms because of excessive number of students have to be properly taken care of.

- Keeping in view the fact that Islamabad is located in relatively cooler zone where the winter season conditions prolong. Properly designed energy saving heating equipment must be provided in sufficient numbers.

- An emergency staircase in each block must be provided with the minimum width of 5 feet between handrails (as recommended by TSS) for exit in case of earth quakes and fire hazard.

- To combat seismic hazards all the new school buildings or additional units built for remodeling must be constructed in frame structure using hollow bricks.

- $\quad$ The safety and security of children must be given priority by building entire boundary wall of at least 2.5 meters height and reconstruct the staircases with standard flight sizes.

- The environmental considerations should be adopted in the light of local prevailing conditions. However, UNESCO standards may also be adopted in certain cases where national standards are not elaborated for finer details.

- The construction of additional blocks should be synchronized with the existing building. A synchronized system of primary school buildings' evaluation and monitoring with respect to their performance accomplishing users and management satisfaction needs to be adopted.

- The remodeling or redesigning of the primary schools has to be based on building performance evaluation.

\section{REMODELING OF EXISTING F.G. JMS G-9/2 BUILDING}

The scope of remodeling envisages making alterations in the existing building as well as constructing new blocks to provide suitable accommodation for all activities in a healthy environment. It may also involve development of open areas to form regular play grounds.

\subsection{Alterations Proposed in Existing Building}

A dire necessity has been assessed with respect to provision of more academic space to combat the need for existing number of children. The chances to provide more academic space are only possible through constructing the new block founded on the lowest level along with minimizing the environmental distractions. Proper daylight may be secured through making new window openings in existing classrooms [Figure-16]. The entrance hall can be lit up by window opening in the blind wall of school office. A multipurpose hall can be sited at a level 1.6 meters below ground level by raising a part of its area from 2.4 meters. The use of energy efficient equipment needs to be emphasized to ensure thermal comfort in the learning areas (such as solar heaters and geysers). At the same time irrigation of trees, flower beds and play ground can be attempted by adopting rain water harvesting system. 


\subsection{Improvements Proposed for Environmental Upgrade}

The improvements in the environmental conditions as well as air movement in existing building will be attained by making alterations. Openings in blind walls by providing windows having the same size as the existing ones can solve the darkness problems in certain areas. All proposed alterations are shown in Figure-16. The central washroom placed in the office room has been shifted for window construction to allow day light exposure. Another window is to be constructed in the office room to gain day light and fresh air movement. A new washroom along with a kitchenette is also proposed for teaching staff [Figure-17]. To obtain day light in the classrooms row of windows are proposed on the verandah side. In order to enhance the lively environment bright color shades are proposed to be applied on doors, windows and interior walls. Proposed windows will help to gain thermal comfort during summer. In winter, provision of energy efficient and safe heating system has been proposed. Tag boards installed on the back walls of classrooms and textured paint can reduce acoustic distractions.

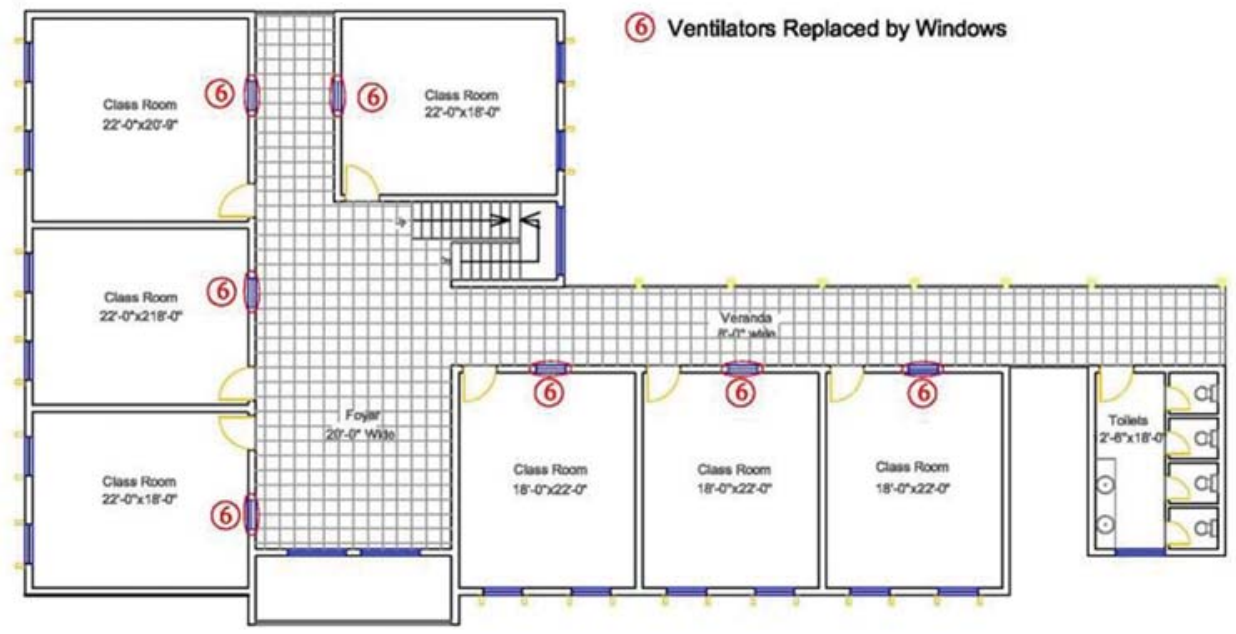

Existing First Floor

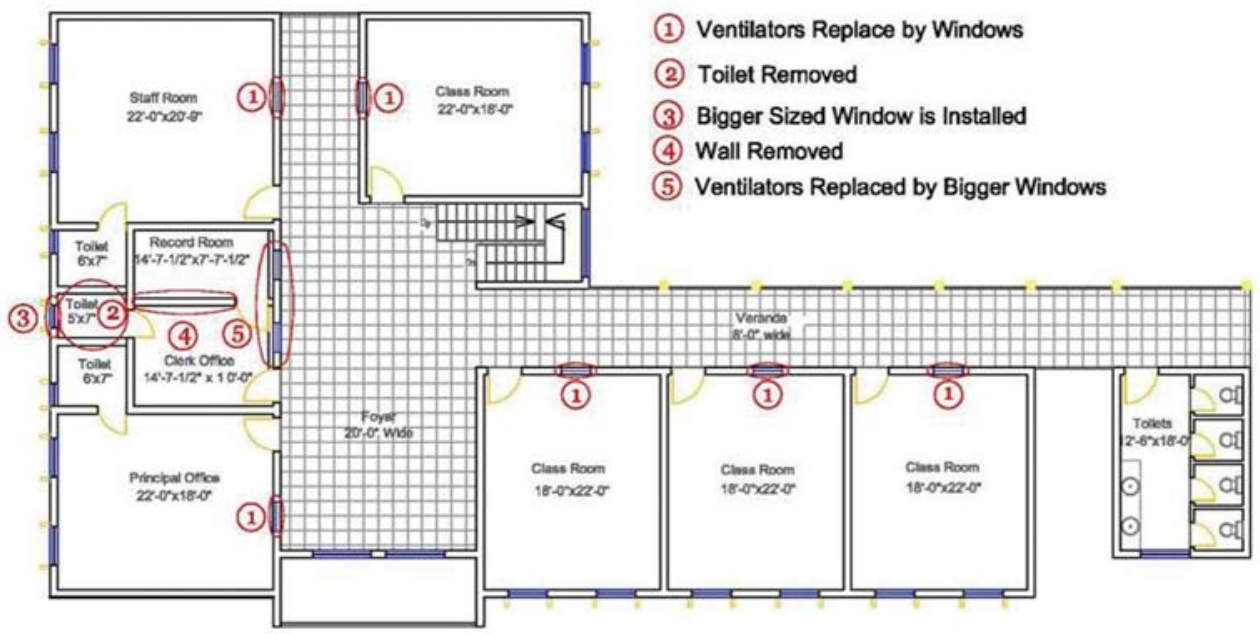

Existing Ground Floor

Figure-16: Alterations Proposed in Existing Building Plan. 


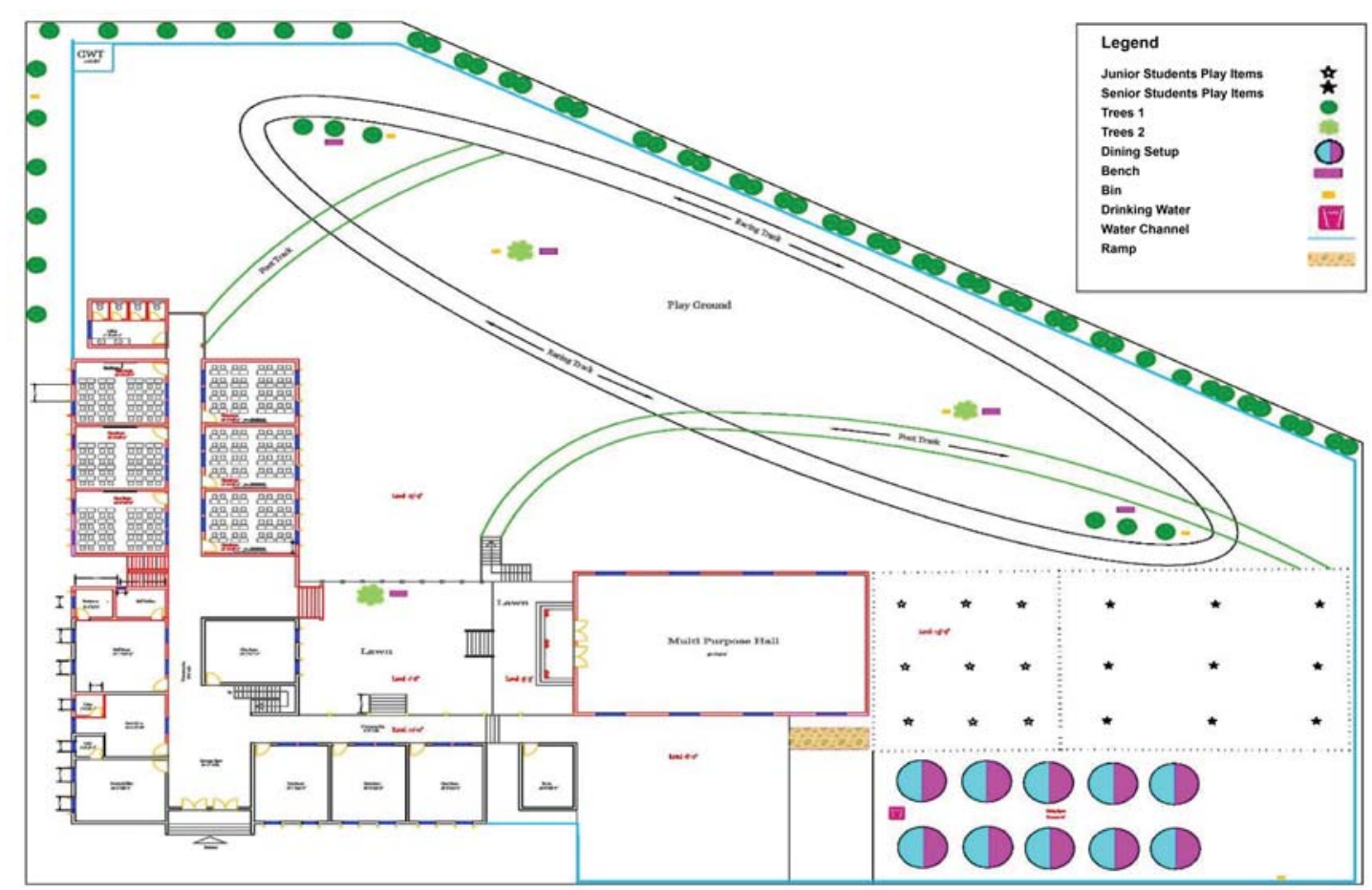

Figure-17: Remodeled Lower Ground Floor Plan.

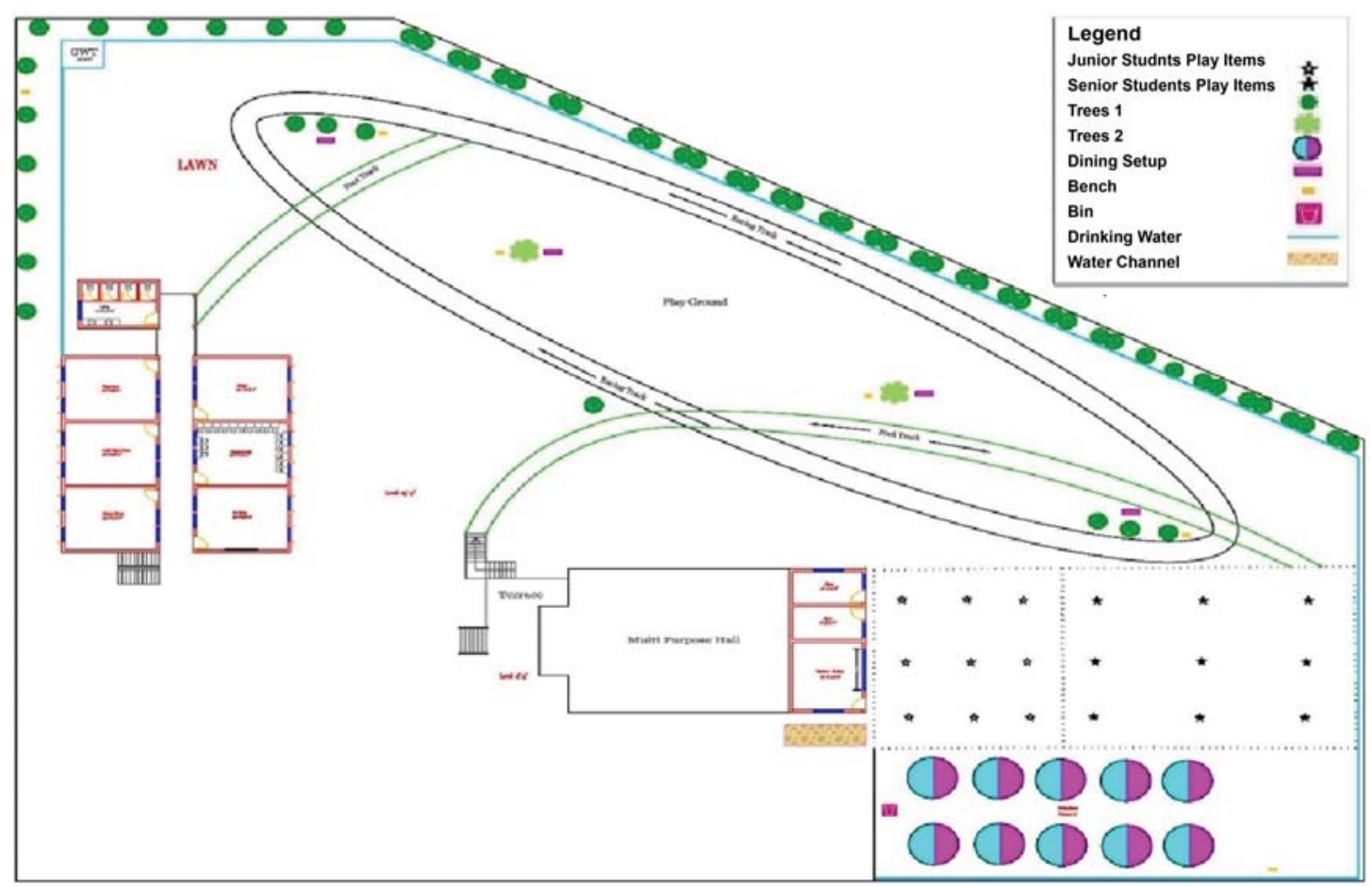

Figure-18: Remodeled Upper Ground Floor Plan. 


\subsection{Proposed Remodeling in the Play Area}

The natural landscape of the area is very attractive having different ground levels. Two lower terraces have been proposed to be designed as lawns [Figure-18]. In the proposal existing stairs towards play ground has also been improved for safety and convenience of the children. A play area has also been proposed to be designed by installing play items for 5 to 8 year and 9 to 11 year children [Figure-19(a-b)] Provision of racing track and installation of benches and bins will improve the usefulness of the area. Plantation of new shady trees has also been proposed to improve thermal comfort and reduce the external noise. A dinning area for about 100 students has been laid out adjacent to the proposed cafeteria [Figure-20].
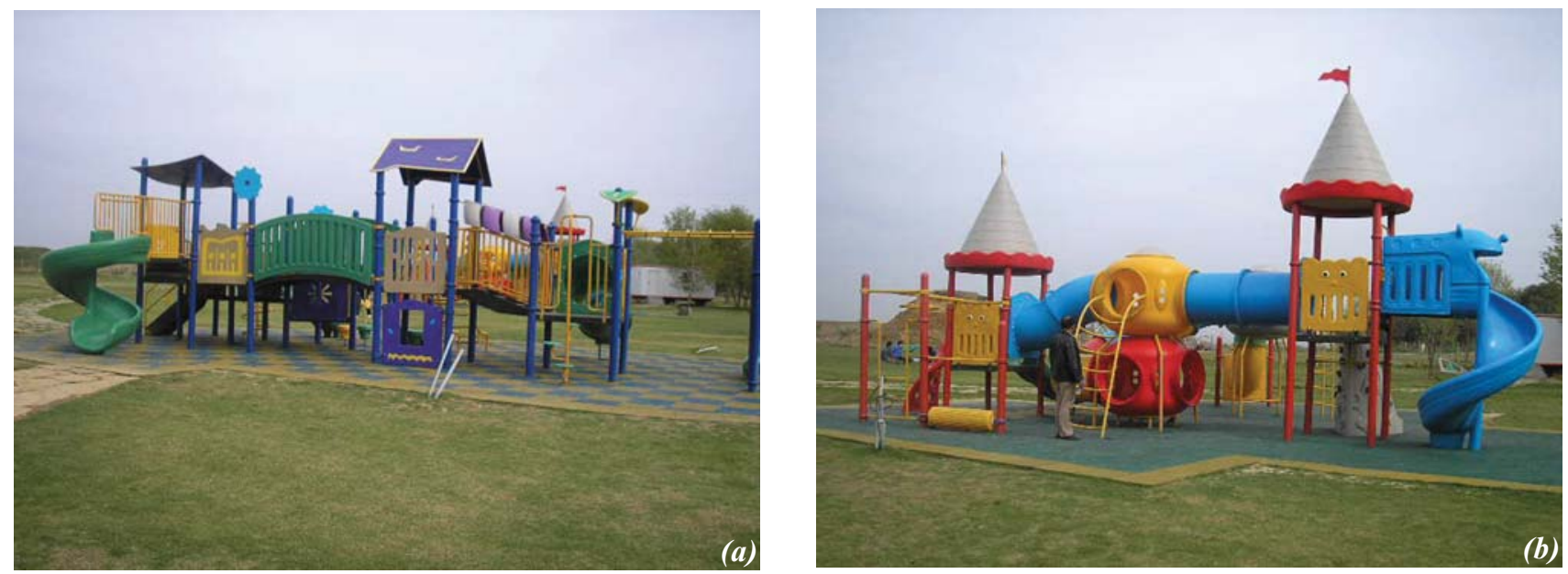

Figure-19(a - b): Proposed playing facility for children-I.

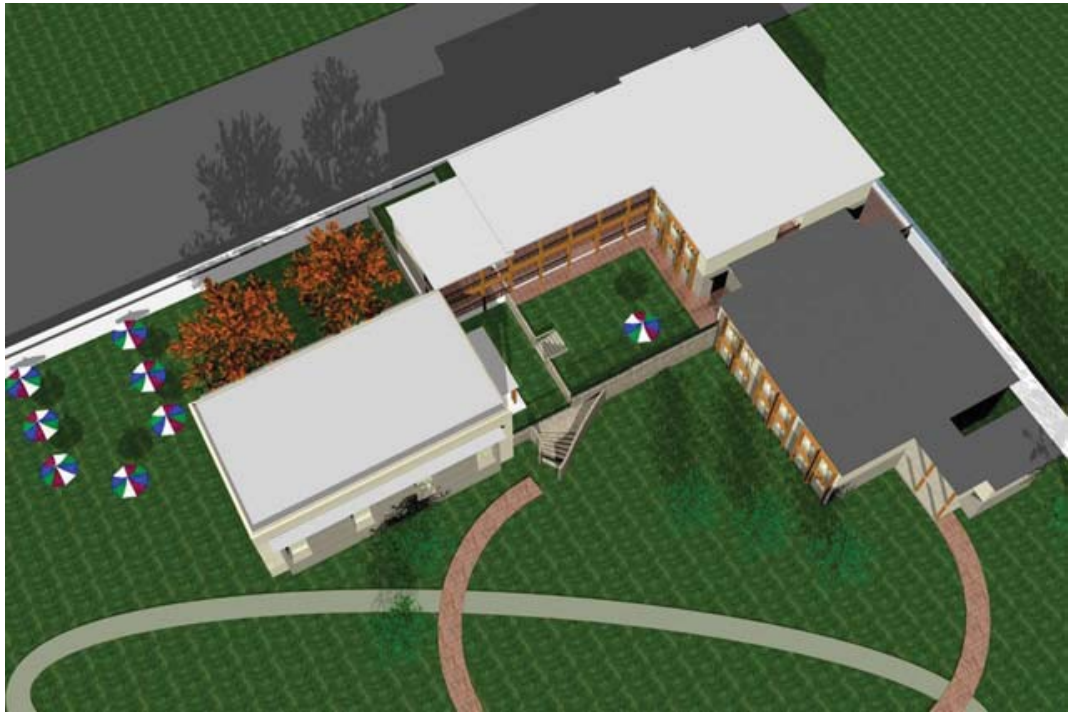

Figure-20: Bird's eye view of the proposed layout showing dining area. 


\subsection{Proposed Extensions In Building}

The construction of a new double storied block containing additional five class rooms to accommodate more sections to reduce number of students to 30 [Figure-18]. A kitchenette and washroom are also proposed adjacent to the staff room with redesigned staircase connecting the upper ground floor with lower ground floor and first floor [Figure-21]. All missing ancillary spaces are suggested in lower ground floor.
Two set of washroom blocks containing four toilets have been added to facilitate students and reducing number of student per washroom to 22. Construction of multipurpose hall of $260 \mathrm{~m}^{2}$ has been proposed to cater indoor plays in summers, assembly in extreme weather and other school functions [Figure-22]. All construction shall be made in frame structure with locally available hollow bricks [Figure$23]$ to provide safety against earthquake hazards.

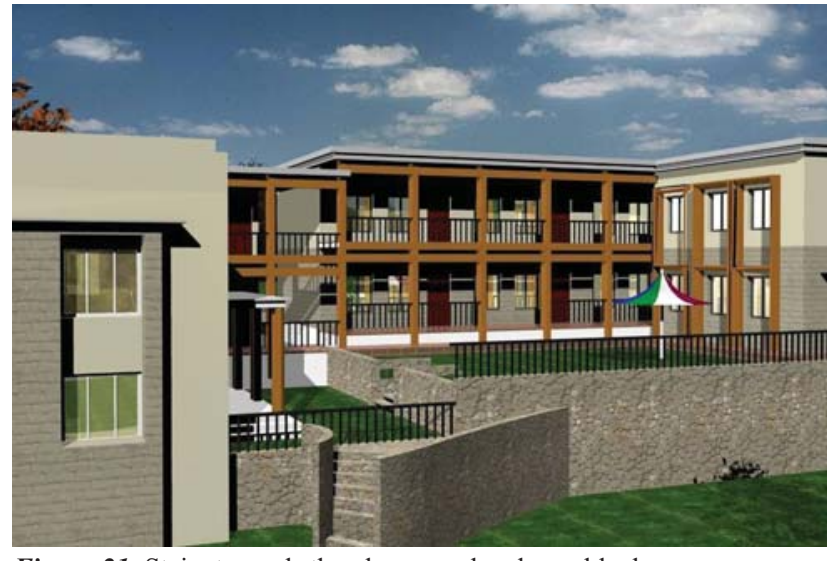

Figure-21: Stairs towards the playground and new block.

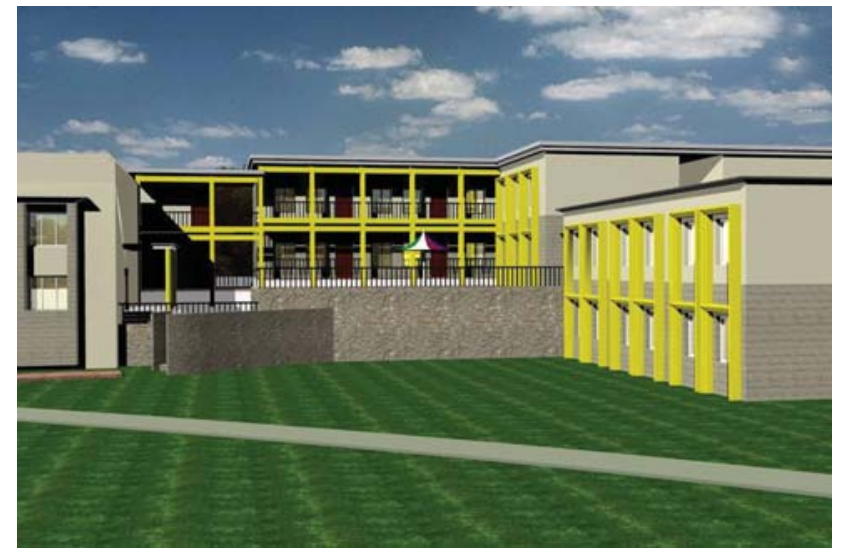

Figure-22: Existing building in centre with new block and multi-purpose hall on right and left sides.

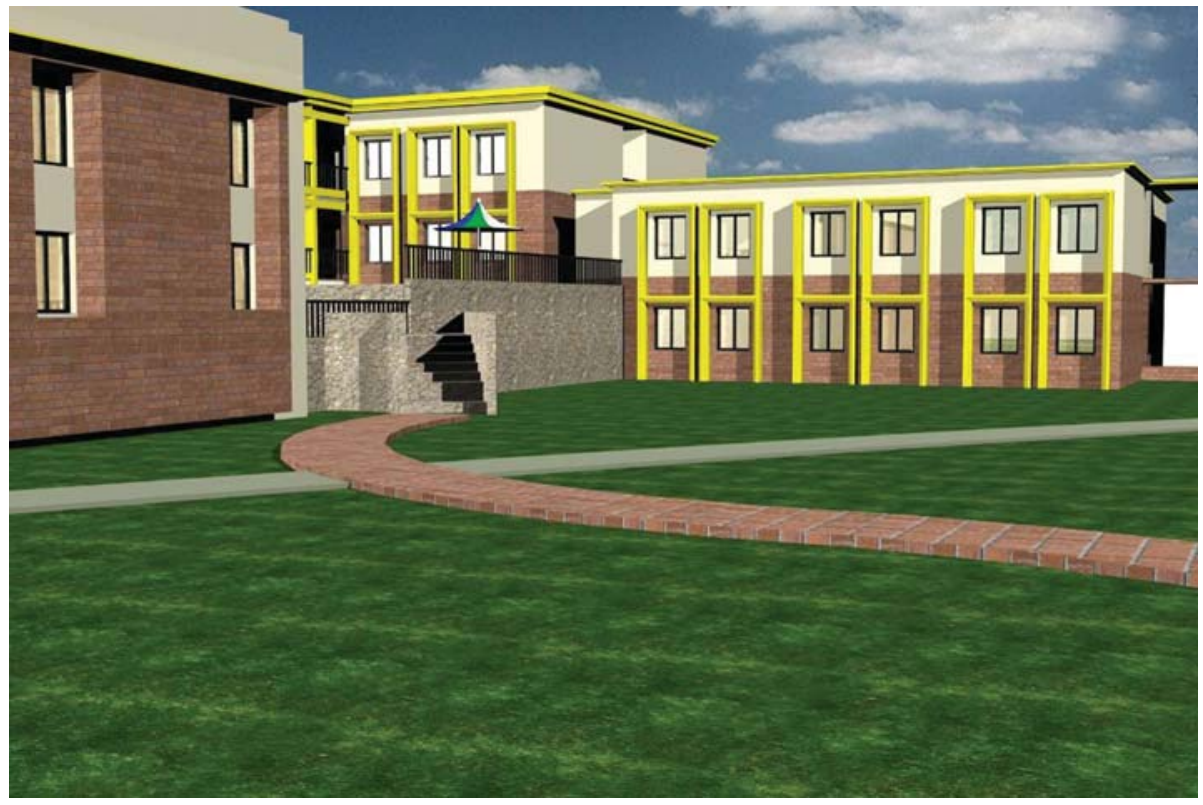

Figure-23: Locally available red bricks on exterior walls. 


\section{CONCLUSIONS}

Employing the Post Occupancy Evaluation technique, the study on Federal Government Private Schools in Islamabad concludes that most schools lack on providing the adequate teaching and learning environment for students and teachers. The main reason for not complying with the students and teachers needs at present is the time-frame as the schools studied were constructed 12 to 30 years back according to perhaps then assessed needs. Over the period the strength of students has increased manifold in the schools under reference. Demand for additional facilities such as computer labs, IT based library and well equipped play grounds is emphasized in new educational policy. These aspects are neglected in the schools studied in spite of open spaces available in the school premises for building extensions.

On the environmental account the perception about thermal comfort is negatively responded by students and teachers for the months of May/June and September mainly due to overcrowded classes and absence of cross-ventilation in some cases (FG JMS G-9/2). During winters most schools are provided with gas-heaters except (FG JMS G-9/2) where complaints were high from both groups of respondents. However, recently due to energy crisis there is load-shedding of gas in peak season that is from December to March and this requires futuristic planning for alternative energy sources such as solar gas heaters. For day light adequacy as all the school buildings are having sufficient open spaces all around therefore perception about availability of daylight and objective measurement with Lux meter has revealed less problem. However, in some buildings particularly FG JMS
F-8/2, FG JMS G-9/2, students and teachers have expressed glare problem and uneven distribution of light throughout the class. As for acoustics, the perception of students and teachers has revealed problems mainly due to over crowding, sound of old ceiling fans and noise from adjacent classrooms. This is further assessed and confirmed through sound meters placed in different locations in the class rooms.

Finally, the school with most complaints from teachers and students and least on checklist developed by researchers and assessed through environmental meters was selected for remodeling to enhance the environmental quality and to meet the current educational needs. Moreover, futuristic sustainable design approach is used to propose the rain water harvesting for landscaping and installation of solar geysers for heating in winters. The current study being first on environmental assessment of schools in Islamabad had been limited in its scope to assess the state of schools covering the students/teachers perception on a few variables. Objective assessment is restricted to Light meter and Sound meter identifying some design flaws. Future studies can be carried out with more detailed systematic assessment with advanced environmental meters studying the indoor and outdoor temperature variables, noise penetration and sunlight. Leadership Energy and Environmental Design (LEED) Standards can also be employed for future research to develop design guidelines in the local context. Comparing the National Standards with UNESCO and TSS, it is proposed to revise the National Standards to include environmental features/aspects in the design guidelines to attain better environmental quality in schools. 


\section{SITE PLANS OF THE SELECTED SCHOOLS}

Case Study - 1: F.G. JMS, F-7/2

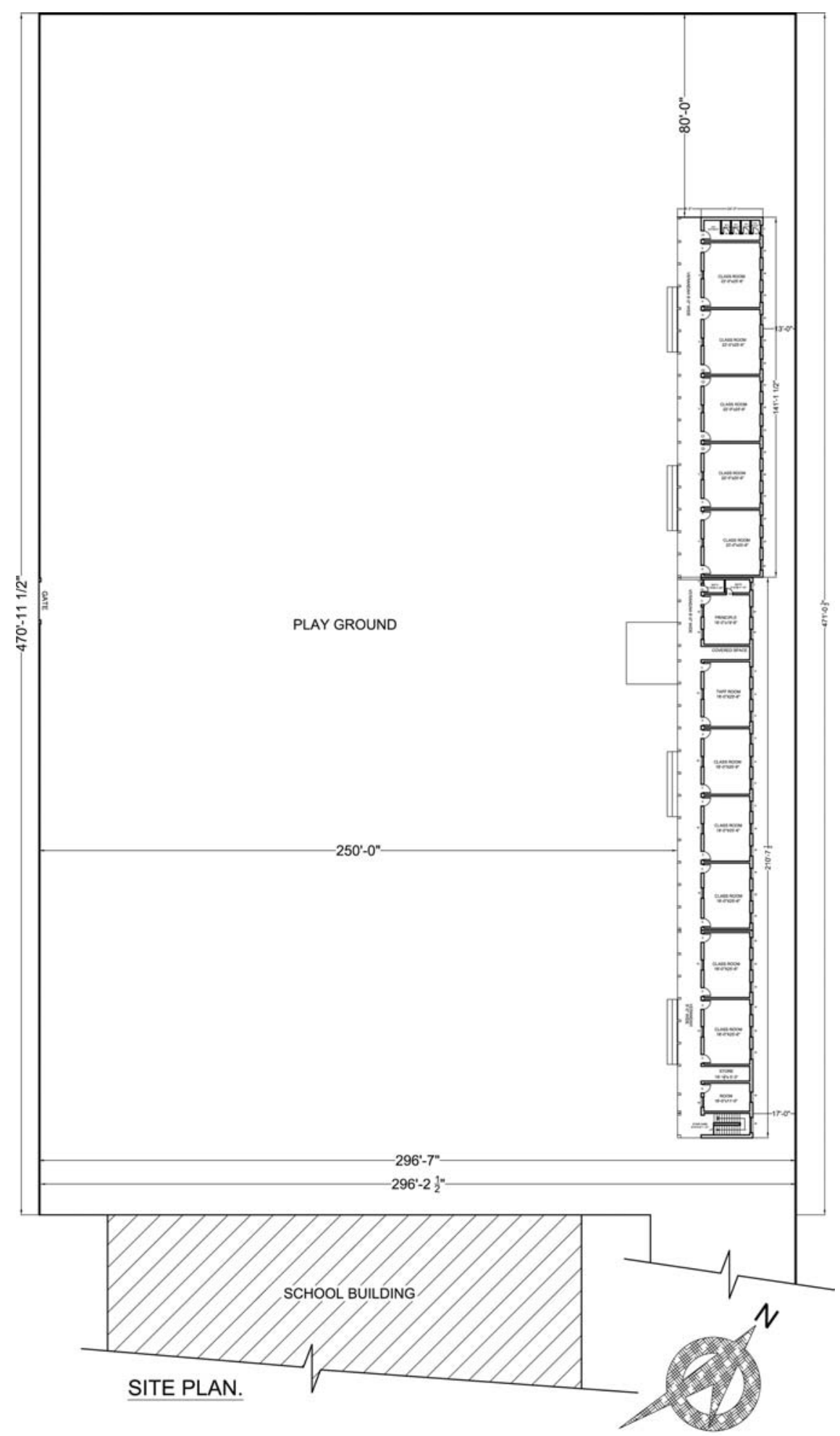


Case Study - 2: F.G. JMS, F-7/2 (Ground Floor and First Floor Plans)

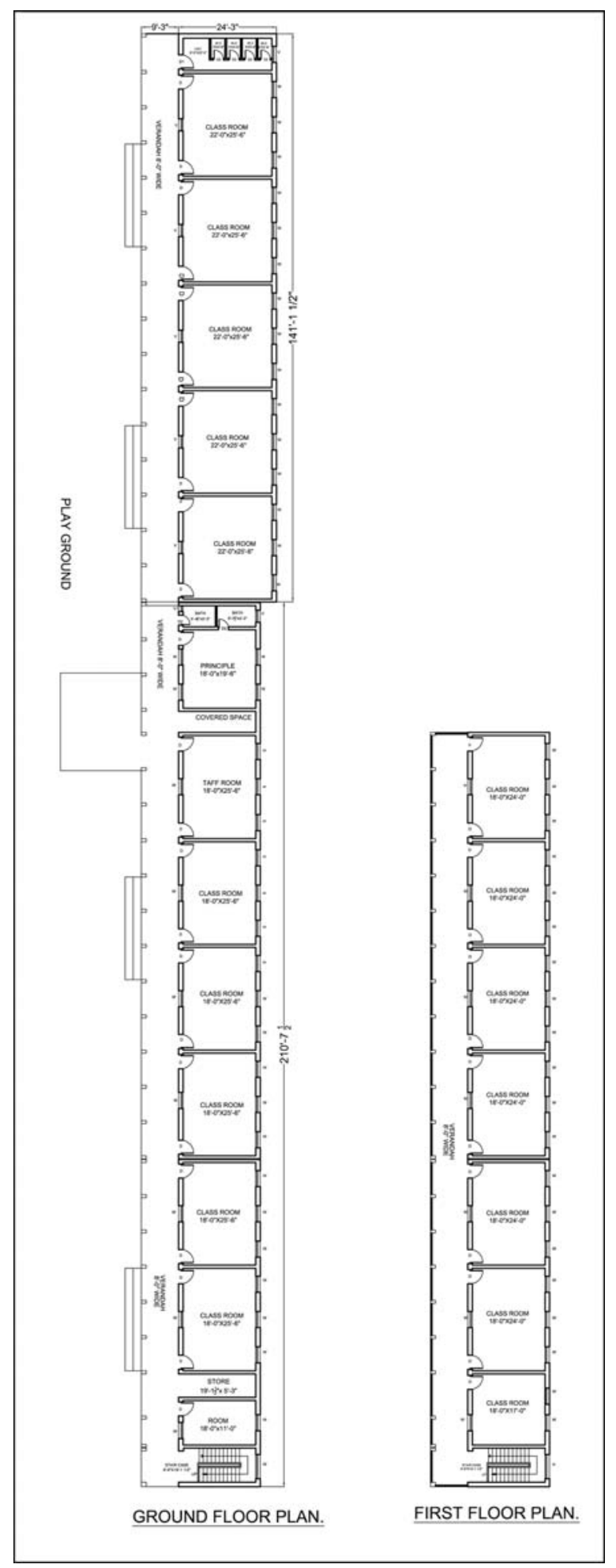


Case Study - 3: F.G. JMS, F-8/2

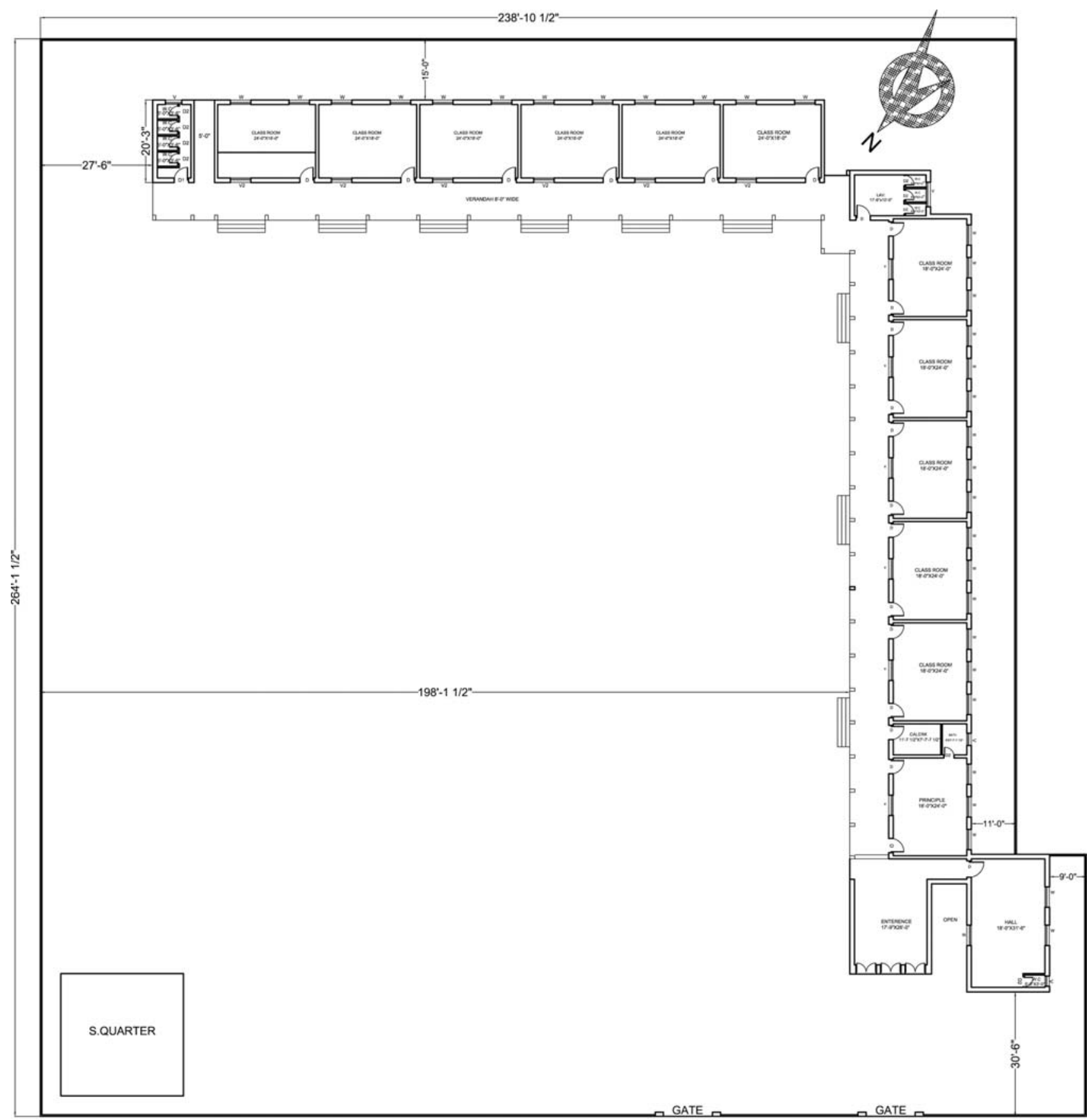

GROUND FLOOR PLAN. 
Case Study - 4: F.G. JMS, I-8/1

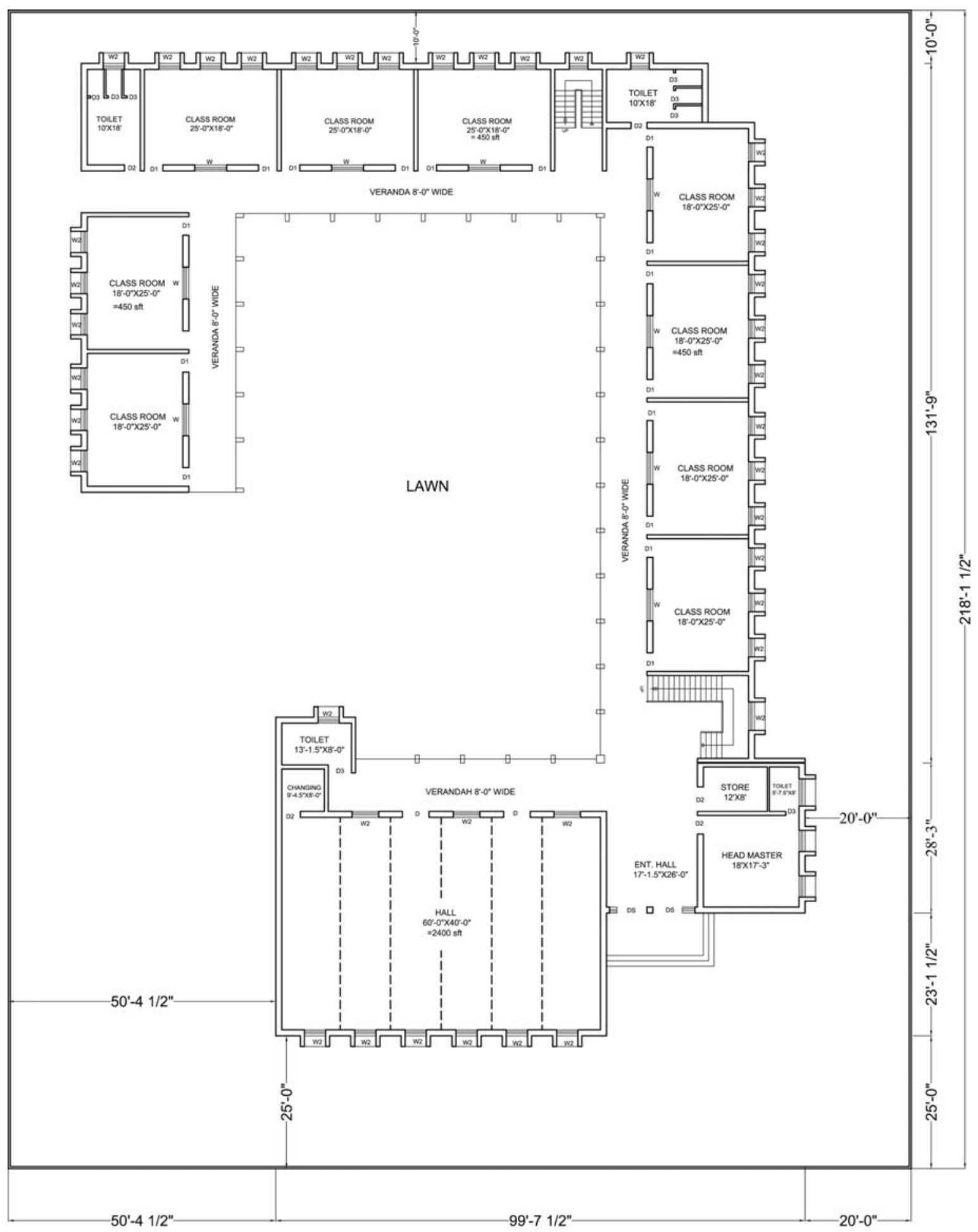

GROUND FLOOR PLAN

COVERD AREA G.FLOOR=12438.5 SFT 
Case Study - 5: F.G. JMS, E-7

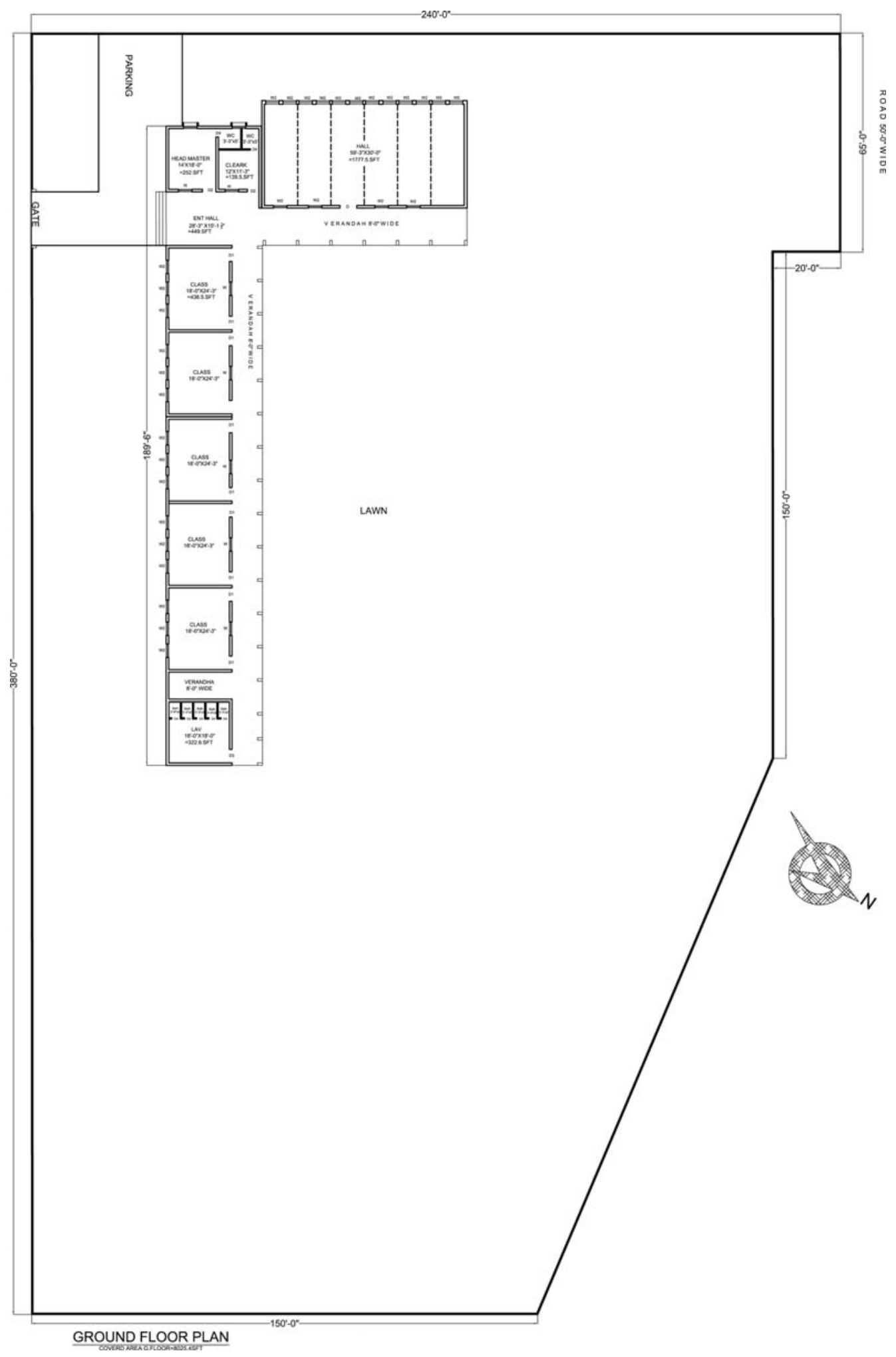


F.G. JMS, G-9/2 (Layout plan and section plan)
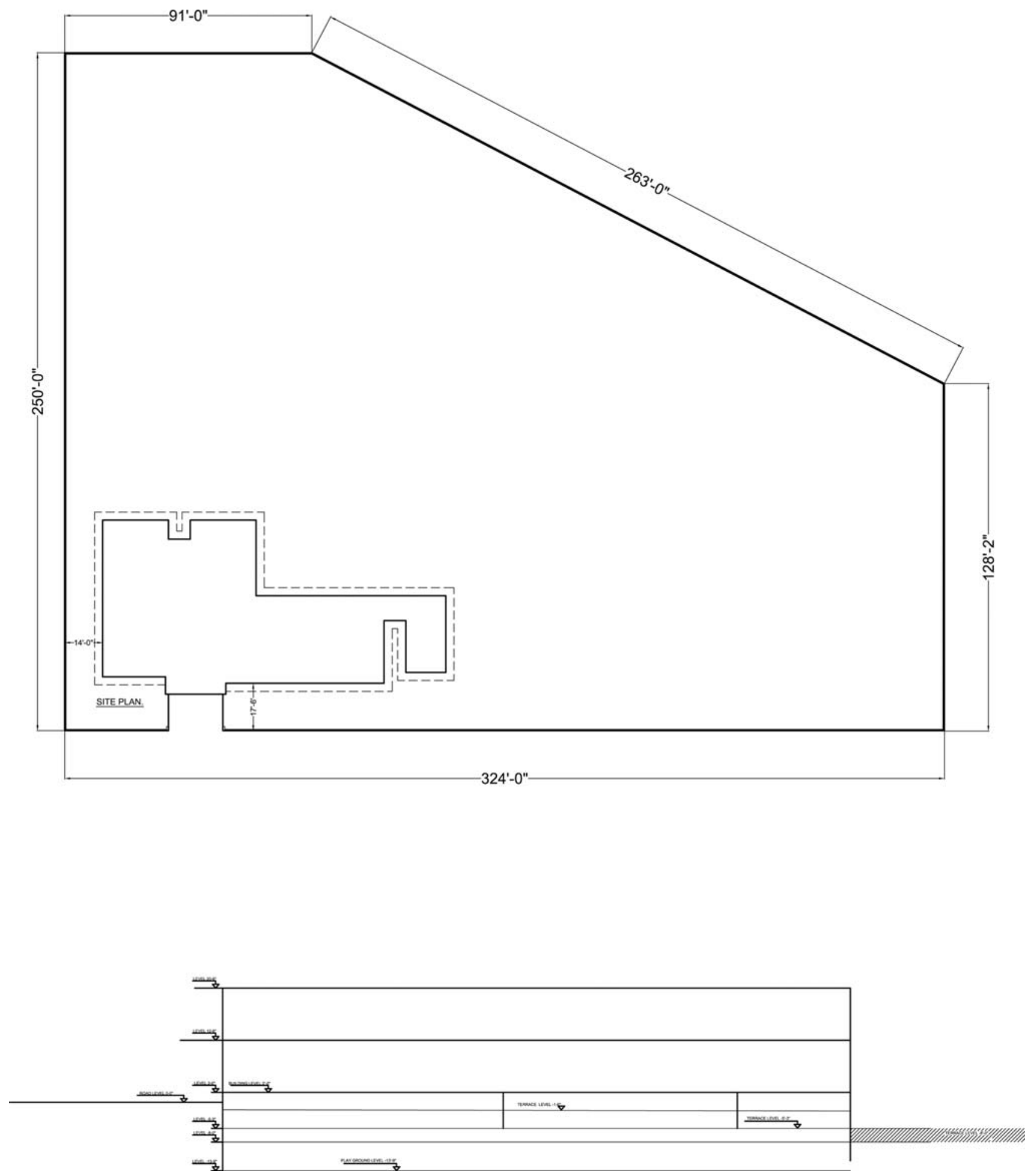

Levels in school selected for remodeling. 
First Floor \& Ground Floor Plan: F.G. JMS, G-9/2

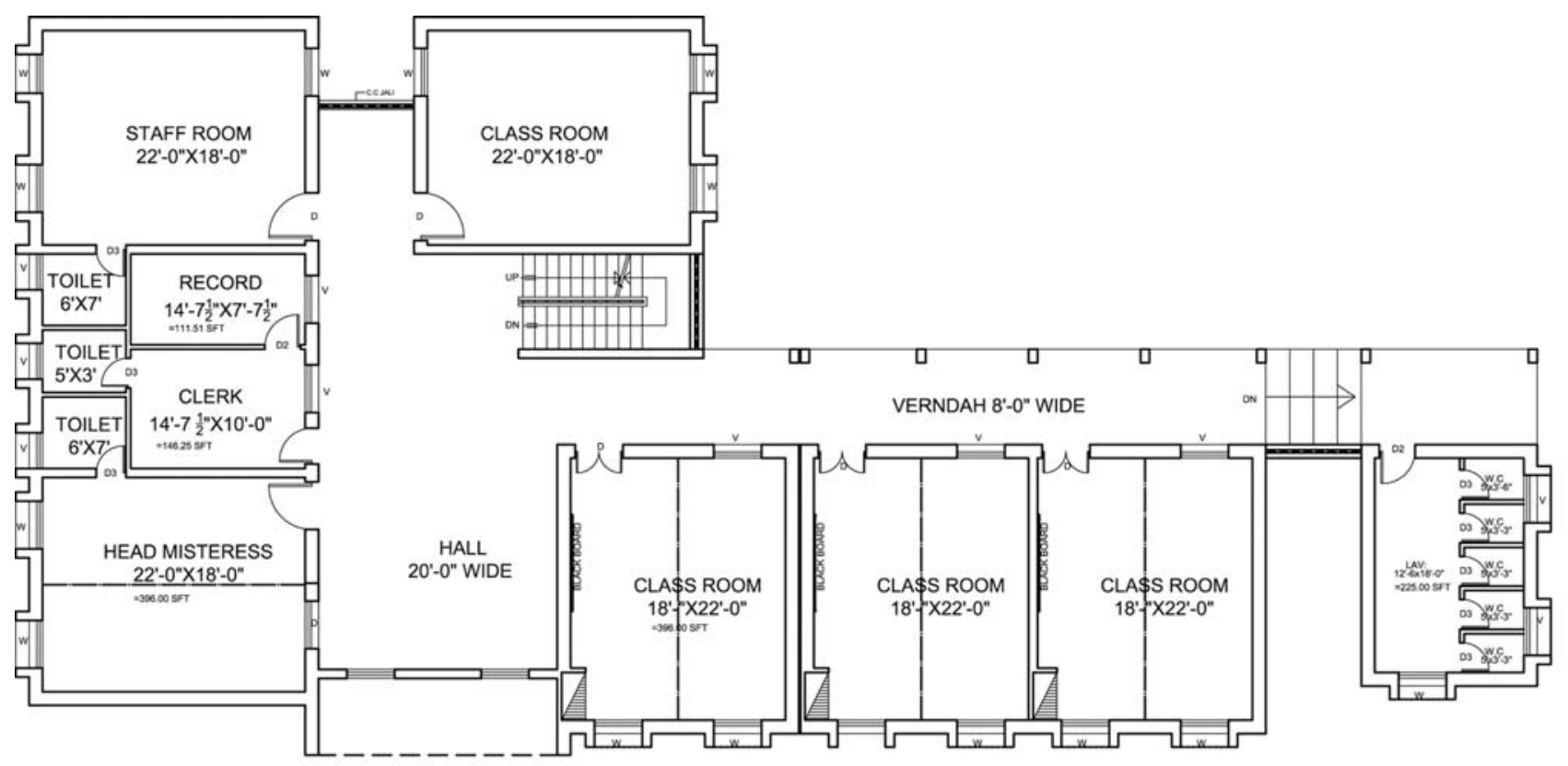

FIRST FLOOR PLAN.

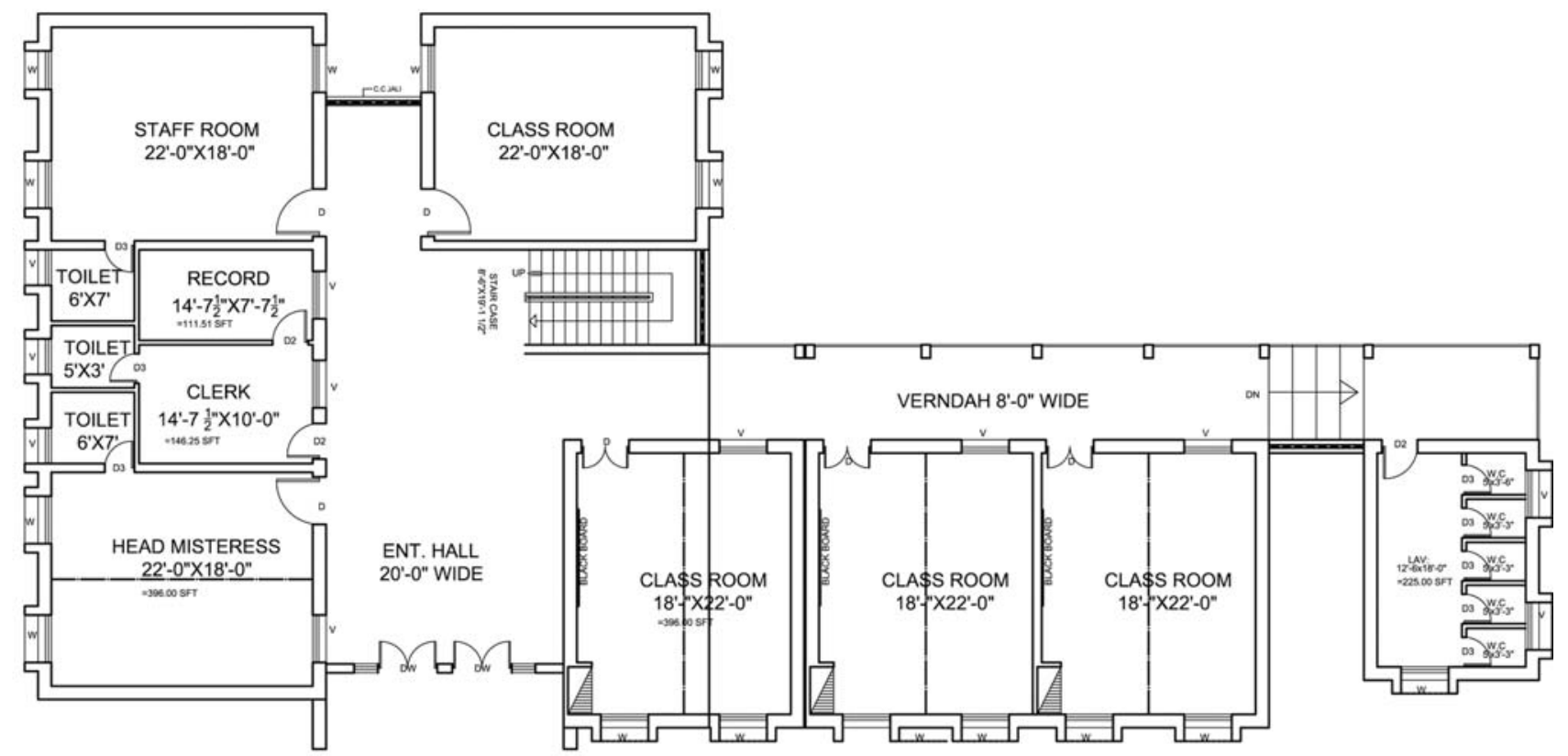

GROUND FLOOR PLAN. 


\section{REFERENCES}

Baird George, John, G., Nigel, I., David, K, Grame, Mc I., Building Evaluation Techniques (1996), the Mc Graw-Hill Conmpanies, Inc (p.129)

Bee, H. Forth Edition, The Developing Child, Harper \& Row Publishers, New York (1985).

Chiara Joseph DE, Crosbie Michael J., Forth Edition, Time Saver Standards for Building Types, 2001, McGraw-Hill.

Chiara J. DE, Crosbie M. J., Forth Edition, Time Saver Standards for Building Types, Mc Grawhill Publishing Company (1990).

Graca, V. A.C, Kowaltowski, D.CCK, Petreche, J. RD, “An evaluation method for school building design at the preliminary phase with optimization of aspects of environmental comfort for the school system of the State Sao Paulo in Brazil", Building and Environment 42984- 999 (2007).

H. Sanoff, School building assessment methods, National Clearinghouse for Educational Facilities, Washington (2001).

Higher Education Funding Council for England (HEFCE), Guide to Post Occupancy Evaluation, (2006), University of Westminster.

Langston C. A. and Ding G. K. C., Second Edition, Sustainable Practices in the Built Environment, Butterworth-Heinemann (2001).

Milla, B. J. Pattison, J. R. "The thermal behavior of an integrated environment school designs: (Elmstead Market County primary) 1974-1975", Building and Environment, Vol. 14-3 167-181. (2003 available on line)

Ohrenshall, M. Better Learning in Better Buildings: Sustainable Design of School Facilities Benefits Educational Mission." CON.WEB - Pacific Northwest Energy Conservation \& Renewable Energy Newsletter: (1999, July 30). 2009

Pere YV, Capeluto, IG "Climatic considerations in school building design in the hot-humid climate for reducing energy consumption” Applied Energy Elsevier Vol. p 86 340-348. (2009)

PPRC, Sustainable Design for Schools, (2004)

Pushkar, S., Becker, P., Katz, A., "A methodology for design of environmentally optimal buildings by variable grouping, Building and Environment 40-8, 1126-1139 (2005)

PEPEC Consultants, National Reference Manual on Planning and Infrastructure Standards, 1986, Government of Pakistan, Ministry of Housing and Works Environment and Urban Affairs Division.

Scheuer, C, Keoleian, G. A., Reppe, P, "Life Cycle energy and environmental performance of a new university building: modeling challenges and design implications" Energy and Buildings 35 1049-1064 (2003)

Shah, A., Anjum. N, Ahsan, H. "Green Building Design-A New Paradigm" paper delivered in International Conference on Science, Technology and Innovation for Sustainable Well-being (STISWB), 23-24 July 2009, Mahasarakhan University, Thailand (2009).

UNESCO Paris, Survey and Evaluation of existing school buildings, 1969, 92p.c, 1975.

Vezzoli, C., "A generation of designers: perspectives for education and training in the field of sustainable design. Experiences and projects at the Politecnico di Milano University, Journal of Cleaner Production, 11, 1-9. (2003).

W.F.E. Preiser and J.C. Vischer, AssessingÊbuilding Êperformance, Elsevier Butterworth Heinemann, Burlington, Ma, EUA (2005).

Zhang, Y., Wang, J., Chen, H, Zhang,J, Meng, Q., “Thermal comfort in naturally ventilated buildings in hot-humid area of China" Building and Environment 45, 2562-2570(2010). 